\title{
Ion-Ion and Ion-Molecule Reactions at the Surface of Proteins Produced by Nanospray. Information on the Number of Acidic Residues and Control of the Number of Ionized Acidic and Basic Residues
}

\author{
Udo H. Verkerk and Paul Kebarle \\ Department of Chemistry, University of Alberta, Edmonton, Alberta, Canada
}

\begin{abstract}
Mass Spectra of charge states of folded proteins were obtained with nanospray and aqueous solution containing $20 \mu \mathrm{M}$ the protein (ubiquitin, cytochrome $c$, lysozyme) and one of the $\mathrm{NaA}$ salts $\mathrm{NaCl}, \mathrm{NaI}, \mathrm{NaAc}$ (acetate) (1-10 mM). At very low collision activated decomposition (CAD), the mass spectra of a protein with charge $\mathrm{z}$ exhibited a replacement of $\mathrm{zH}^{+}$with $\mathrm{zNa}^{+}$and also multiple adducts of NaA. Higher CAD converts the $\mathrm{NaA}$ adduct peaks to Na minus $\mathrm{H}$ peaks. These must be due to loss of HA where the $\mathrm{H}$ was provided by the protein. The degree of HA loss with increasing CAD followed the order $\mathrm{I}<\mathrm{Cl}<\mathrm{Ac}$. Significantly, the intensity of the ions with $\mathrm{n}(\mathrm{Na}$ minus $\mathrm{H})$ adducts showed a downward break past an $n_{\operatorname{MAX}}$ which is equal to the number of acidic residues of the protein plus the charge of the protein. All the observations could be rationalized within the framework of the electrospray mechanism and the charge residue model, which predict that due to extensive evaporation of solvent, the solutes will reach very high concentrations in the final charged droplets. At such high concentrations, positive ions such as $\mathrm{Na}^{+}$, $\mathrm{NH}_{4}^{+}$form ion pairs with ionized acidic residues and the negative $\mathrm{A}^{-}$form ion pairs with ionized basic residues of the protein. Adducts of $\mathrm{Na}^{+}$, and NaA to backbone amide groups occur also. This reaction mechanism fits all the experimental observations and provides predictions that the number of acidic and basic groups at the surface of the gaseous protein that remain ionized can be controlled by the absence or presence of additives to the solution. (J Am Soc Mass Spectrom 2005, 16, 1325-1341) (c) 2005 American Society for Mass Spectrometry
\end{abstract}

$\mathrm{I}$

$n$ this work, we will consider reactions of ions $\mathrm{M}^{+}$, $\mathrm{BH}^{+}, \mathrm{A}^{-}$, and the ion pairs (salts) MA and BHA, with residues and peptide backbone located at or near the surface of proteins. $\mathrm{M}^{+}$are ions such as the alkali ions, $\mathrm{BH}^{+}$are protonated bases such as ammonia and the alkyl amines, and $\mathrm{AH}$ are acids such as the halide acids $\mathrm{HCl}, \mathrm{HI}$, or carboxylic acids such as acetic acid AcH. Such reactions can be inferred from the mass spectra obtained when the salt is present in the aqueous solution of a protein that is subjected to electrospray ionization (ESI) or nanospray ionization (NSI). In analytical mass spectrometry of proteins and other biomolecules, the presence of salts such as alkali ion and particularly $\mathrm{Na}^{+}$salts in the solution has long been recognized to lead to peptide or protein mass spectra that are "messy" because of the presence of salt ion adducts that interfere with the interpretation of the

Published online June 24, 2005

Address reprint requests to Dr. P. Kebarle, Department of Chemistry, University of Alberta, E3-44, Edmonton, Alberta T6G 2G2, Canada. E-mail: paul.kebarle@ualberta.ca mass spectra [1]. When the salt is not easily removed from the solution, which is most often the case, addition of ammonium acetate can lead to clean protein spectra [1h]. Clearly, it is desirable to understand the processes that are responsible for these observations.

Our interest in these reactions is based also on a long quest to interpret the mass spectra obtained with ESI and NSI on the basis of the processes that lead from ions in solution to the ions in the gas-phase that are observed in the spectrum $[2,3]$.

The present work aims to provide a systematic study of: (1) the formation of the adducts within the framework of the ESI, NSI mechanism and the conditions present in the interface to the mass spectrometer; (2) the sites on the protein with which the adducts bond; (3) the mechanism of the reactions that occur when protein-adduct complexes are subjected to CAD. The present work deals only with folded proteins, i.e., proteins that are essentially nondenatured. Answers to (1), (2), and (3) above are obtained by comparing mass spectra obtained with selected, different salts and by exposing these different adducts to CAD. Most experi- 
ments involve ubiquitin. This protein was chosen because it is relatively stable, i.e., it remains folded even in the absence of a buffer salt like ammonium acetate [4]. It also leads to a very narrow distribution of charge states and one dominant, $Z=6$, charge state.

The findings of the study do not only provide some answers to questions (1)-(3), but have also analytical utility. They provide a rational for the observed clean mass spectra when certain conditions such as acetic acid or ammonium acetate are used as additives to the solution, and "messy" spectra when other additives such as alkali salts are present in the solution. Also, there have been extensive studies aimed at characterizing the multiply charged proteins observed in the gas-phase by subjecting them to ion-molecule reactions and studies based on mobility determinations that provide information on the changes of the conformation of the proteins when certain conditions are imposed. It has been recognized that to make reasonable comparisons of structural data obtained by different laboratories, it is important that the conditions used to form the ions must be well characterized [4]. While characterizing the conditions is essential, it is also important to know what the causes are for the changes. The present work provides answers to some of these questions.

Because the mechanism by which the multiply charged proteins are produced by ESI has a bearing on the present work, a brief outline of the important features is given below.

Electrospray in the positive ion mode produces positively charged droplets because an electrolysis process at the positive electrode leads to the formation of $\mathrm{H}_{3} \mathrm{O}^{+}$ and, thus, to an excess of positive relative to negative ions in the solution $[5,6]$. The charged droplets produced at the spray tip evaporate rapidly at constant charge. This brings the charges closer together. At the Rayleigh stability limit, the Coulomb repulsion between the charges on the surface just balances the droplet cohesion because of the surface tension of the solvent. Droplet fission occurs at or very near that limit. A number of smaller offspring droplets are released by the fission. These carry off a small fraction of the volume but a much larger fraction of the charge of the parent droplet. A succession of such evaporation followed by fission events reduces the parent droplet to a very small size. Because of the large decrease of volume by evaporation, in the presence of buffer salts, the parent droplets become saturated on solute and ultimately become charged salt particles. The first generation offspring droplets also evaporate fast and can undergo fission leading to second generation droplets. Early graphic representations of such droplet histories [2] could be replaced by more accurate droplet histories [7] that are based on recent observations by Beauchamp and coworkers [8].

De la Mora [9] has provided important evidence that the charged folded proteins are produced in the gasphase by the charged residue model (CRM). The key evidence used by de la Mora was the finding that the number of charges $Z_{P}$ of a large number of folded proteins observed in the literature are very close to the Rayleigh limit of solvent droplets of the same size as the protein, see Figure 1, [9]. De la Mora had deduced in earlier work that a parent droplet just after a fission is below the Rayleigh limit but still quite close to it. This means that the droplets remain all the time close to the Rayleigh limit. The recent experiments by Beauchamp and coworkers [8] provide proof for this assumption. De la Mora [9] reasoned that a very small droplet that had just undergone fission and happens to have a volume close to that of the protein, on evaporating to dryness, will transfer its charge to the protein without further fissions. When the solvent is gone, the protein will be overall neutral and so the charge of the protein $Z_{P}$ will be equal to the charge of the droplet. Therefore, the protein charge $Z_{P}$ will be very close to the charge at the Rayleigh limit, $Z_{R S}$, for a droplet with the same size as the protein:

$$
\mathrm{Z}_{\mathrm{P}} \approx \mathrm{Z}_{\mathrm{RS}}
$$

$Z_{\mathrm{RS}}$ can be evaluated with the Rayleigh equation and the radius of the protein. A radius can be assigned to the protein only when it is folded. Therefore, the charge of unfolded, denatured proteins can not be quantitatively predicted with CRM [9].

De la Mora did not consider the chemistry of the protein charging process. Felitsyn et al. [10a] reasoned that in the presence of a buffer salt like $\mathrm{NH}_{4} \mathrm{Ac}$, the charges on the droplet will be predominantly $\mathrm{NH}_{4}^{+}$ions and in this case the charging will be due to proton transfer reactions from $\mathrm{NH}_{4}^{+}$to basic residues at or near the surface of the protein. The mechanism of charging by proton transfer was developed further by Peschke et al. [10b] and Verkerk et al. [10c], who came to the conclusion that in the presence of ammonium acetate, the charging occurs by $\mathrm{NH}_{4}^{+}$that forms adducts either with the acidic ionized residues or with neutral basic residues.

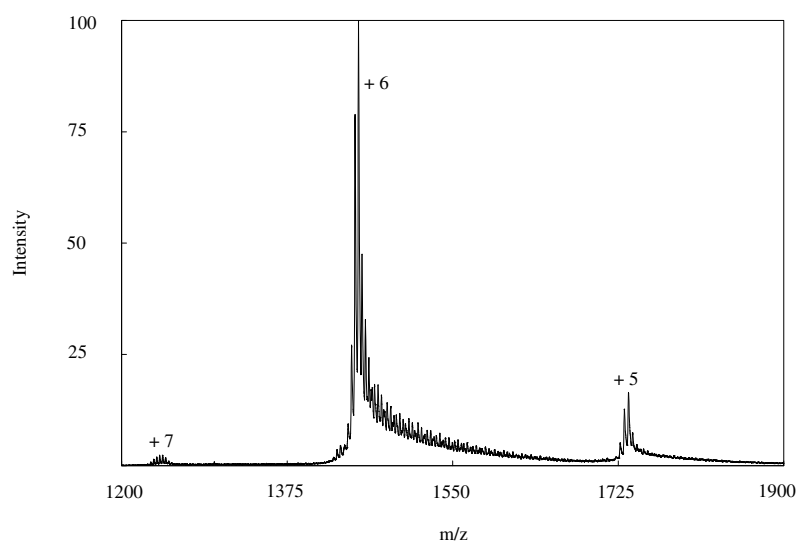

Figure 1. Mass spectrum of $25 \mu \mathrm{M}$ ubiquitin, $1 \mathrm{mM} \mathrm{NaCl}$ at a low CAD of $160 \mathrm{~V}$. Figure shows that the +6 charge state is dominant. 
The CRM mechanism, apart from determining the number of charges of the proteins, has other consequences. Because in general the final precursor droplet has a volume that is larger than the volume of the protein, on evaporation of the droplet all the solute present in the droplet will end up on the protein. Typical solutes will be the buffer salt. The solute that ends up on the protein will be observed as an adduct to the protein, provided that the ions and ion pairs of the solute find sites on the protein with which they can form noncovalent bonds. The bonds must be strong enough to survive the clean up stage in the interface to the mass analysis, i.e., the heated sampling capillary and the subsequent CAD stage [7, 10c]. The droplet history given in [7] indicates ${ }^{\circ}$ that ${ }^{\circ}$ the ${ }^{\circ}$ observed ${ }^{\circ}$ protein ions, when NSI is used, originate mostly from the first generation offspring droplets.

\section{Experimental}

\section{Materials and Solutions Used}

Ubiquitin (bovine red blood cells), cytochrome $c$ (horse), and lysozyme (chicken egg white) were purchased from Sigma (St. Louis, MO) and used without further purification. A stock solution of a protein was prepared using deionized water and refrigerated between use at $-20{ }^{\circ} \mathrm{C}$. Chlorine-35 (99\%) enriched sodium chloride was obtained from Aldrich (Milwaukee, WI), sodium iodide and sodium acetate were obtained from Anachemia (Montreal, QC, Canada).

An aliquot of a protein stock solution was diluted using salt solution to give a $0.5 \mathrm{ml}$ solution with a final concentration of $20-25 \mu \mathrm{M}$ protein. The $\mathrm{pH}$ of the 25 $\mu \mathrm{M}$ ubiquitin/1 mM sodium iodide and sodium chloride solutions was 5.9 The $\mathrm{pH}$ of the $25 \mu \mathrm{M}$ ubiquitin/5 $\mathrm{mM}$ sodium acetate, $20 \mu \mathrm{M}$ lysozyme $/ 10 \mathrm{mM}$ sodium acetate, and $21 \mu \mathrm{M}$ cytochrome $c / 10 \mathrm{mM}$ sodium acetate solutions was $6.5,6.1$, and 6.7 , respectively.

\section{Mass Spectrometry}

A Mariner Biospectrometry workstation (TOF, PerSeptive Biosystems, Framingham, MA) was used for these studies. For instrumental details, see previous publications ${ }^{\circ}\left[7,{ }^{\circ} 10 \mathrm{c}\right] .{ }^{\circ}$ Mass $^{\circ}$ calibration $^{\circ}$ was $^{\circ}$ performed ${ }^{\circ}$ using $^{\circ}$ a $50 \times 10^{-3} \mathrm{M}$ cesium iodide solution in $50 \%$ acetonitrile/ water $[11 \mathrm{~b}] .{ }^{\circ} \mathrm{It}^{\circ}$ was $^{\circ}$ observed $^{\circ}$ that ${ }^{\circ}$ increasing ${ }^{\circ}$ the ${ }^{\circ}$ nozzleskimmer voltage decreased the measured spray current. Therefore, to maintain the same spray current while increasing the nozzle skimmer voltage, the spray volt-

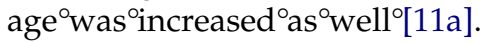

\section{Data Collection}

Mass spectra were obtained by averaging 100-200 spectra, each $3 \mathrm{~s}$ per spectrum. The final spectrum and peak positions were obtained after a 9 points Gaussian smoothing of the averaged spectrum using the Mariner
Explorer software. Low S/N ratios for the low intensity peaks in the front and tail sections of a charge state cluster lead to significant errors in individual peak assignment. However, the constant spacing between peaks in a series allows assignment of the adduct formation, as any mass assignment error would show up as an increase of the difference between calculated and measured mass within a series. While ubiquitin and cytochrome $c$ solutions gave a well defined single charge state of high intensity, lysozyme solutions gave a series of charge states varying between +10 and +7 , with only the +8 and +9 showing significant sodiation or adduct formation. Similar observations have also been ${ }^{\circ}$ reported ${ }^{\circ} \mathrm{by}^{\circ} \mathrm{Schmidt}$ et al. [11a].

\section{Electrospray Conditions}

The ${ }^{\circ}$ spray ${ }^{\circ}$ tip position $(2 \mathrm{~mm}$ in front of the sampling capillary), curtain gas flowrate $(2.2 \mathrm{~L} / \mathrm{min})$, and sampling capillary temperature $\left(35^{\circ} \mathrm{C}\right)$ were the same for all experiments. The electrospray voltage was applied to a platinum wire inserted inside the capillary. During the experiment, the ion emission current was measured using a floating $\mu \mathrm{A}$ meter. Experiments with varying nozzle-skimmer voltage were done without changing the spray tip.

Various combinations of tip diameter, current, and concentration were tried to maximize adduct formation and signal intensity, while minimizing signal instability during signal accumulation. Spray tip diameter and current are factors that determine the solution flow rate and initial droplet diameter, and are therefore critical parameters ${ }^{\circ}$ in $^{\circ}$ adduct $^{\circ}$ formation, ${ }^{\circ}$ see $^{\circ}$ Schmidt $^{\circ}$ et $^{\circ}$ al. [11a]. ${ }^{\circ}$ For cytochrome $c$ and ubiquitin, spray tips with a tip diameter of $4 \pm 1 \mu \mathrm{m}$ (BG-12-94-4-N-20, New Objective, Woburn, MA) functioned best, while for lysozyme a tip diameter of $1 \pm 0.5 \mu \mathrm{m}$ (BG-12-94-1-N20) gave the best results. The sodium chloride and sodium iodide spectra were recorded with a current of 36 and $33 \mathrm{nA}$. The sodium acetate spectra were recorded with currents of 65,52 , and $23 \mathrm{nA}$ for cytochrome $c$, ubiquitin, and lysozyme.

\section{Results and Discussion}

\section{Ubiquitin, $\mathrm{NaCl}, \mathrm{NaI}$, and NaAcetate Adducts and CAD* Products Observed in the Mass Spectra}

Mass spectra obtained with nanospray and $25 \mu \mathrm{M}$ ubiquitin and $\mathrm{mM}$ concentrations ${ }^{\circ}$ of $^{\circ} \mathrm{NaA}{ }^{\circ}$ in $^{\circ}$ water ${ }^{\circ}$ are shown ${ }^{\circ}{ }^{\circ}{ }^{\circ}$ Figures $^{\circ} 1^{\circ}$ to $^{\circ} 9 .^{\circ}$ For $^{\circ}$ details ${ }^{\circ}$ of ${ }^{\circ}$ procedures ${ }^{\circ}$ and apparatus ${ }^{\circ}$ used, ${ }^{\circ}$ see $^{\circ}$ the ${ }^{\circ}$ Experimental $^{\circ}$ section. ${ }^{\circ}$ Figure ${ }^{\circ} 1$ shows ${ }^{\circ}$ the ${ }^{\circ}$ charge $^{\circ}$ states observed with $\mathrm{NaCl}$ and demonstrates that the $\mathrm{Z}=6$ state is completely dominant. This was the case also with the other $\mathrm{NaA}$ salts used. Therefore, the discussion of the results will be based on the results for the $Z=+6$ state. The selection of the + 6 charge state has also another advantage. Work by Clemmer ${ }^{\circ}$ and $^{\circ} \operatorname{coworkers}^{\circ}[12]^{\circ}$ has $^{\circ}$ shown $^{\circ}$ that ${ }^{\circ}$ this ${ }^{\circ}$ state 


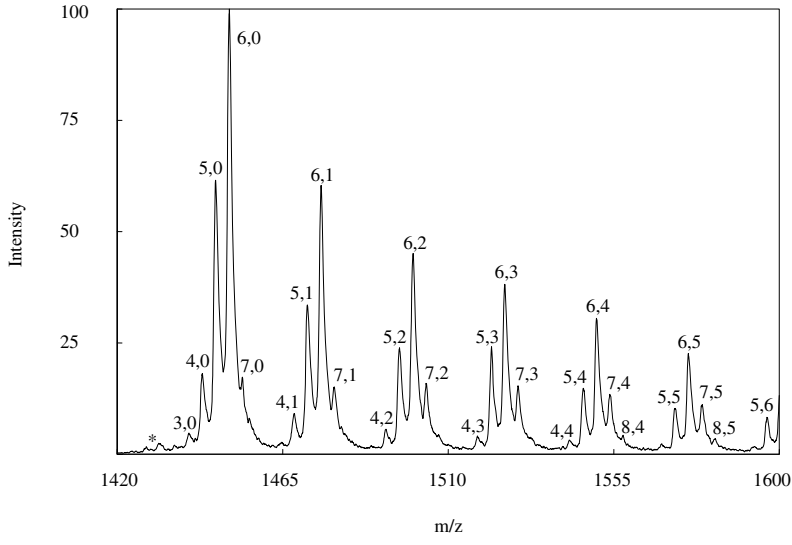

Figure 2. Expanded mass spectrum of $Z=6$ charge state of 25 $\mu \mathrm{M}^{\circ}$ ubiquitin, ${ }^{\circ} 1 \mathrm{mM}^{\circ} \mathrm{NaI}^{\circ}$ at $^{\circ} \mathrm{a}^{\circ} \mathrm{low}^{\circ} \mathrm{CAD}^{* \circ} \mathrm{of}^{\circ} 160^{\circ} \mathrm{V}$. .Peaks ${ }^{\circ}$ denoted as $\mathrm{n}, 0$ have $\mathrm{nNa}$ atoms where each $\mathrm{Na}$ has replaced one $\mathrm{H}$ atom originating from the charged protein. The second number $\mathrm{s}$ in the designation $\mathrm{n}, \mathrm{s}$ gives the number of $\mathrm{NaA}$ adducts. The intensity of the $\mathrm{NaI}$ adducts is very much higher than the intensity of $\mathrm{NaCl}$ adducts under similar conditions; see Figures 5, 6. This indicates that the $\mathrm{NaI}$ ion pairs form much more stable adducts than the $\mathrm{NaCl}$ ion pairs do. Peaks indicated with an asterisk have not been assigned.

remains essentially compact (folded) for trapping times as long as $1 \mathrm{~s}$, while the +7 and +8 states convert into more open conformations after some $10 \mathrm{~ms}$.

The mass spectra, Figures 19011 , were obtained with a given potential drop between the transfer capillary tip (nozzle) and the first (cone) electrode in the interface to the mass spectrometer. The total ion intensity decreases rapidly ${ }^{\circ}$ below ${ }^{\circ} 160^{\circ} \mathrm{V},{ }^{\circ}$ and ${ }^{\circ}$ in $^{\circ} a^{\circ}$ previous $^{\circ}$ work $^{\circ}[13]^{\circ}$ we came to the conclusion that the dissociation of weakly bonded complexes begins to occur near $160 \mathrm{~V}$ potential. While we will call the dissociation due to higher nozzlecone potentials $\mathrm{CAD}$, the pressure past the tip of the transfer capillary is very high and the electric field gradient is also very high. At these conditions, an ion is expected to undergo thousands of collisions before the decomposition occurs. These are not typical CAD con-

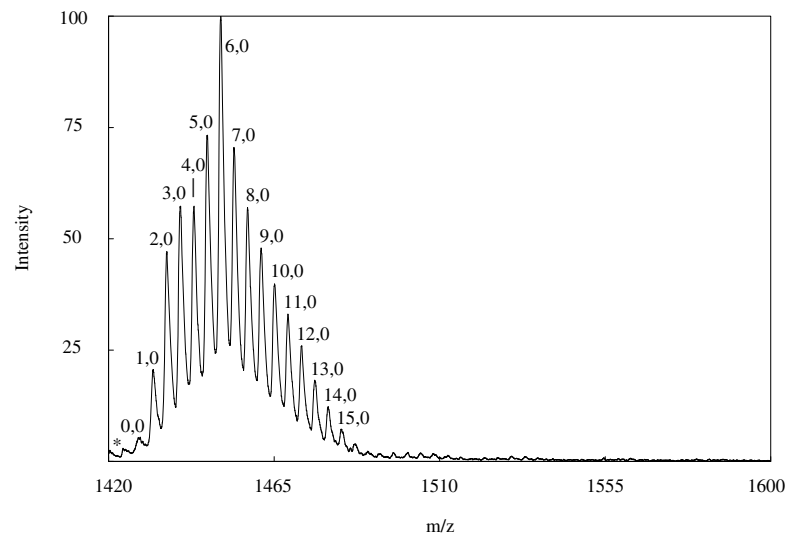

Figure 3. Ubiquitin ${ }^{\circ}$ Under $^{\circ}$ same $^{\circ}$ Conditions $^{\circ}$ as $^{\circ}$ in ${ }^{\circ}$ Figure $^{\circ} 2^{\circ}$ but ${ }^{\circ}$ at a high $\mathrm{CAD}^{*}$ of $450 \mathrm{~V}$. Peaks with $\mathrm{NaI}$ adducts have been converted to $\mathrm{n}, 0$ ions by loss of HI. Peaks indicated with an asterisk have not been assigned.

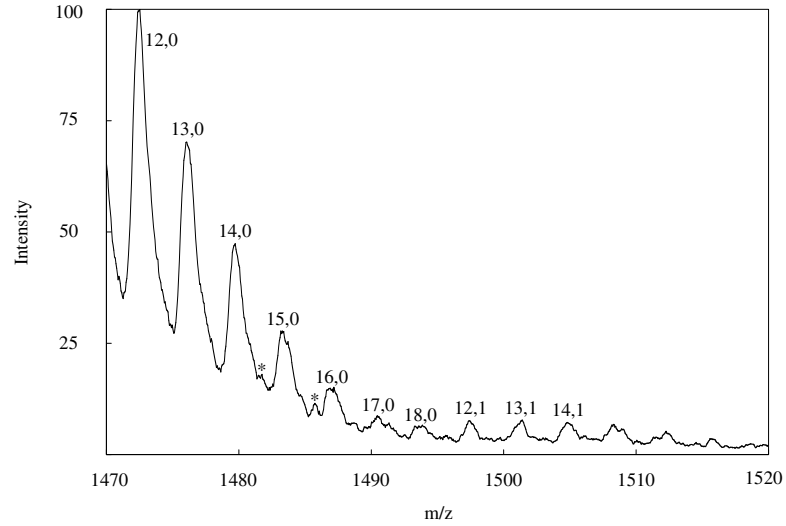

Figure 4. Ubiquitin, ${ }^{\circ}$ same $^{\circ}$ spectrum ${ }^{\circ}$ as in $^{\circ}$ Figure $^{\circ} 3^{\circ}$ but $^{\circ}$ with extended mass range above $n, 0$ peak with $n=11$. Spectrum shows last ${ }^{\circ} n, 0^{\circ}$ peak ${ }^{\circ}$ with $^{\circ}$ observable ${ }^{\circ}$ intensity at $n=18$.

ditions. They are closer to increases of the internal energy of the ions as it occurs in ion drift tubes at high electric fields and high gas densities, see appendix in $[14 \mathrm{a}] . .^{\circ} \mathrm{To}^{\circ}$ distinguish ${ }^{\circ}$ between the ${ }^{\circ}$ conventional ${ }^{\circ} \mathrm{CAD}$ and the present $\mathrm{CAD}$, we ${ }^{\circ}$ will use the notation $\mathrm{CAD}^{*}$ for the present conditions. Another distinction between $\mathrm{CAD}$ and $\mathrm{CAD}^{*}$ is that the presence of a minimum nozzle cone potential difference is required for focusing of the ions that leads to an efficient ion transmission. Potential differences significantly lower than $160 \mathrm{~V}$ were not used in the present work because they led to much lower ion intensities. This effect is probably due to reduced ion focusing at low nozzle to cone potentials. A comparison between ion dissociation due to nozzle skimmer potential and conventional CAD is available in the literature ${ }^{\circ}[14 \mathrm{~b}] .^{\circ} \mathrm{An}^{\circ}$ obvious $^{\circ}$ disadvantage $^{\circ}$ with $\mathrm{CAD}^{*}$ is that the ions subjected to activation have not been separated by $m / z$ selection. The dominance of the $\mathrm{z}^{\circ}={ }^{\circ} 6^{\circ}$ state demonstrated ${ }^{\circ}$ in $^{\circ}$ Figure $^{\circ} 1^{\circ}$ provides $^{\circ}$ some assurance that most of the $\mathrm{CAD}^{*}$ products will be attributable to the $\mathrm{z}=6$ state. Another disadvantage suggested by one of the reviewers is that the CAD* may involve proteins that are not fully desolvated because of

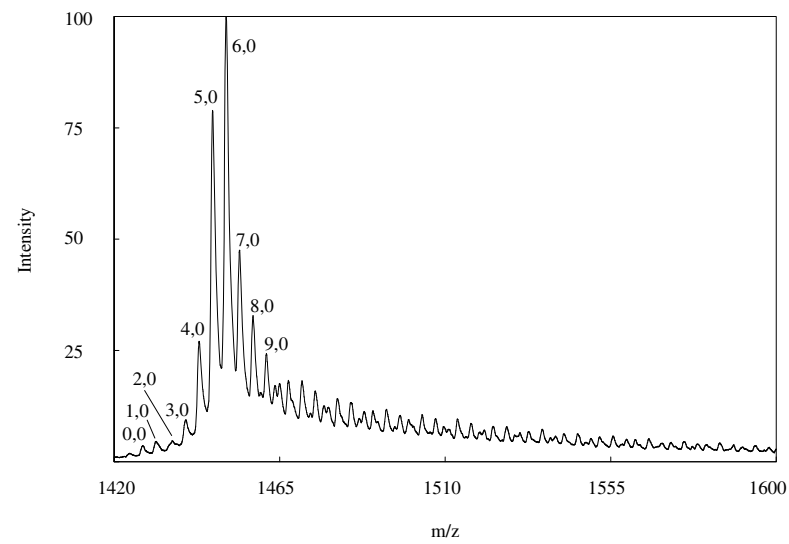

Figure 5. Ubiquitin ${ }^{\circ} 25^{\circ} \mu \mathrm{M},{ }^{\circ} \mathrm{NaCl}^{\circ} 1^{\circ} \mathrm{mM},{ }^{\circ}$ at ${ }^{\circ} \mathrm{low}^{\circ} \mathrm{CAD}^{* \circ} 160^{\circ} \mathrm{V}$. Intensities of the $\mathrm{NaCl}$ adducts are very low. Peaks attributable to $\mathrm{s}^{\circ} \mathrm{NaCl}^{\circ}$ adducts ${ }^{\circ}$ are $^{\circ}$ identified ${ }^{\circ}{ }^{\circ}{ }^{\circ} \mathrm{Figure}^{\circ} 6$. 


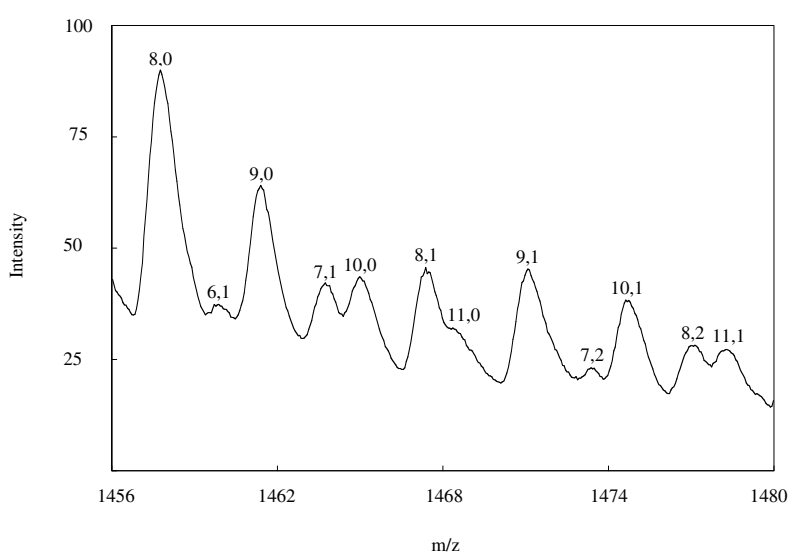

Figure 6. $25 \mu \mathrm{M}, \mathrm{NaCl} 1 \mathrm{mM}$. Expanded part of spectrum in Figure ${ }^{\circ} 5^{\circ}$ shows $^{\circ}$ overlap $^{\circ}$ of ${ }^{\circ} n, 0^{\circ}$ series $^{\circ}$ with $^{\circ}$ the ${ }^{\circ} \mathrm{n}, \mathrm{s}^{\circ}$ series $^{\circ}$ where ${ }^{\circ} \mathrm{s}$ stands for the number of $\mathrm{NaCl}$ adducts to the protein. The ion 8,1 is the first of the $s>0$ series that has a higher intensity than the $n, 0$ series in that mass region. Very low intensity of ions up to $n, s=$ 12,23 could be positively identified.

incomplete evaporation of the droplets. We are confident that this is not the case with the apparatus that we use. The nanospray droplets are very small, with an approximate radius of $0.15 \mu \mathrm{m}$ at the flow rates that we use, and they are expected to evaporate within less than $200^{\circ} \mu \mathrm{s}^{\circ}[7] .^{\circ}$ Therefore, ${ }^{\circ}$ the ${ }^{\circ}$ droplet $^{\circ}$ evaporation ${ }^{\circ}$ will ${ }^{\circ}$ be close to complete before the droplets enter the transfer capillary, and if not, then certainly complete by the time they exit the heated transfer capillary.

\section{$\mathrm{NaI}$}

Figure $2^{\circ}$ gives $^{\circ}$ the ${ }^{\circ}$ expanded ${ }^{\circ}$ mass $^{\circ}$ spectrum ${ }^{\circ}$ of ${ }^{\circ}$ the ${ }^{\circ} \mathrm{z}^{\circ}=$ 6 charge state obtained with $25 \mu \mathrm{M}$ ubiquitin and $1 \mathrm{mM}$ $\mathrm{NaI}$ in aqueous solution and $160 \mathrm{~V} \mathrm{CAD}^{*}$ potential. The major peaks are easily identified. Starting from the low mass end, six groups of peaks are observed. The mass

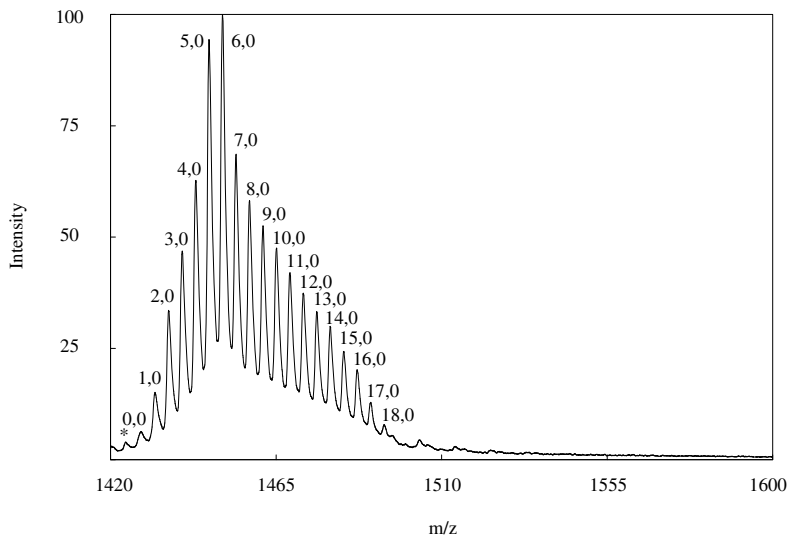

Figure 7. Ubiquitin ${ }^{\circ}$ under $^{\circ}$ same $^{\circ}$ Conditions $^{\circ}{ }^{\circ}{ }^{\circ}$ in $^{\circ}$ Figures $^{\circ} 5^{\circ}$ and $^{\circ} 6$ but with a high $\mathrm{CAD}^{*}$ of $450 \mathrm{~V}$. Intensity of $n, 0$ peaks with $n$ bigger than 6 has increased dramatically. The generation of these peaks from the $s>0$ series requires loss of $\mathrm{HCl}$. Last $\mathrm{n}, 0$ peak with noticeable intensity occurs at $n=18$. The peak indicated with an asterisk has not been assigned.

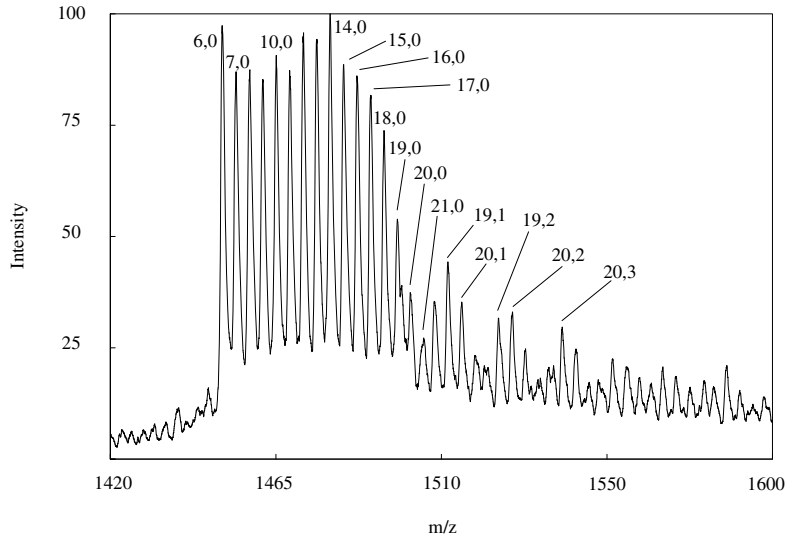

Figure 8. Ubiquitin spectrum $25 \mu \mathrm{M}$ ubiquitin, $5 \mathrm{mM}$ sodium acetate $\mathrm{NaAc}$ at a low $\mathrm{CAD}$ of $160 \mathrm{~V}$. High initial concentration of $\mathrm{NaAc}$ and higher solution flow rates used lead to large number of salt adducts to protein. These lose HAc readily leading to the observed high intensity n, 0 adducts with high n. However, some $\mathrm{NaAc}$ adducts are left; see peaks 20,$1 ; 20,2 ; 20,3$ etc.

increase between the successive groups corresponds to the NaI mass. The increase of mass between ions within each group is 22 mass units, which corresponds to a gain of one $\mathrm{Na}$ and the loss of $\mathrm{H}$. The mass of all ions observed in the spectrum can be represented by the eqs $2 a$ and $2 b$, where $2 b$ stands for mass spectra observed with other charge states $\mathrm{z}$ :

$$
\begin{aligned}
\text { Mass of ion } & =\mathrm{P}+\mathrm{nNa}+(6-\mathrm{n}) \mathrm{H}+\mathrm{sNaA} \\
& =\mathrm{P}+\mathrm{nNa}+(\mathrm{z}-\mathrm{n}) \mathrm{H}+\mathrm{sNaA}
\end{aligned}
$$

$\mathrm{P}$ stands for the molecular mass of the protein (ubiquitin), $\mathrm{Na}$ for the mass of sodium, $\mathrm{H}$ for the mass of the $\mathrm{H}$ atom, and $\mathrm{NaA}$ the mass of the salt ion pair used. The peaks ${ }^{\circ}$ in ${ }^{\circ}$ the ${ }^{\circ}$ spectra, ${ }^{\circ}$ Figures ${ }^{\circ} 2-11$, ${ }^{\circ}$ are ${ }^{\circ}$ identified ${ }^{\circ}$ by the values of $n$ and $s$, i.e., $(n, s)$.

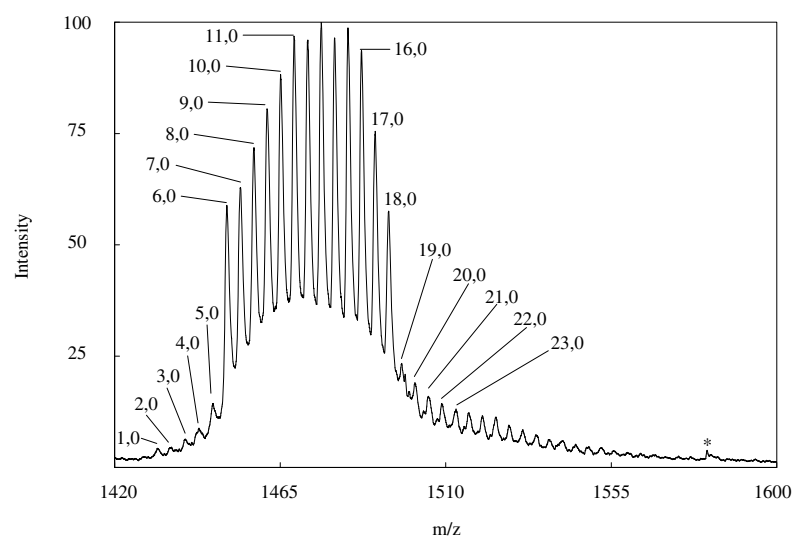

Figure 9. Ubiquitin ${ }^{\circ} \mathrm{at}^{\circ}$ same $^{\circ}$ conditions $^{\circ}$ as in ${ }^{\circ}$ Figure $^{\circ} 8^{\circ}$ but $^{\circ}$ at $^{\circ}$ a high ${ }^{\circ} \mathrm{CAD}$ of $375 \mathrm{~V}$. Because of extended loss of HAc, the $n, 0$ series is very prominent. This series shows a sharp break on intensity past $\mathrm{n}=18$. This $\mathrm{n}_{\mathrm{MAX}}=18$ value corresponds to the number of acidic $^{\circ}$ groups $^{\circ}$ on $^{\circ}$ the ${ }^{\circ}$ surface $^{\circ}$ of ${ }^{\circ}$ ubiquitin, ${ }^{\circ}$ Nacid $+z$, where Nacid $=12$, see Table $1 \mathrm{a}^{\circ}$ and $^{\circ}$ the ${ }^{\circ}$ charge $\mathrm{o}^{\circ}{ }^{\circ}$ the $e^{\circ}$ protein ${ }^{\circ}$ is $\mathrm{z}=6$. 


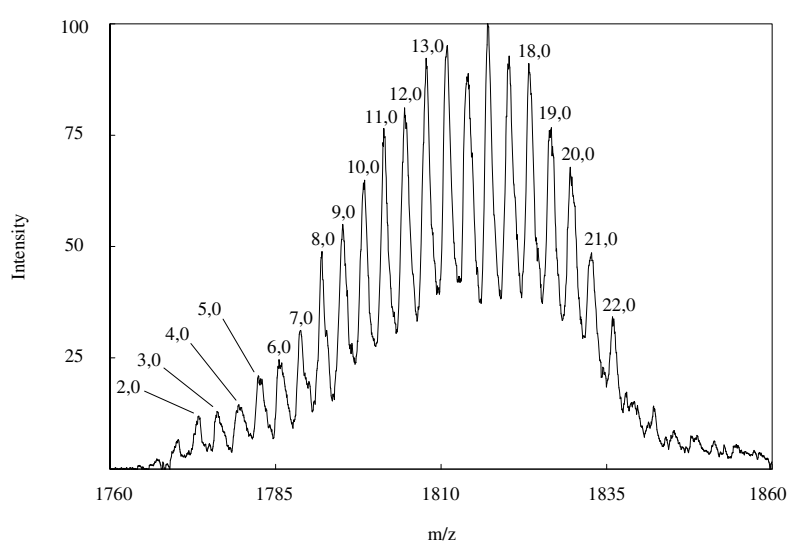

Figure 10. Spectrum of $\mathrm{z}=7$, charge state of $21 \mu \mathrm{M}$ cytochrome c, $10 \mathrm{mM} \mathrm{NaAc}$ at a high CAD of $400 \mathrm{~V}$. Peaks n,0 show a sharp break at $\mathrm{n}=22$. This $\mathrm{n}_{\mathrm{MAX}}=22$ value corresponds to the total number ${ }^{\circ}$ of $^{\circ}$ acidic $^{\circ}$ groups $^{\circ}$ in $^{\circ}$ cytochrome $^{\circ} \mathrm{C},{ }^{\circ} \mathrm{Nacid}^{\circ}={ }^{\circ} 15,{ }^{\circ}$ see $^{\circ}$ Table $1 \mathrm{~b},{ }^{\circ}$ plus ${ }^{\circ}$ the ${ }^{\circ}$ charge $^{\circ} \mathrm{z} ;{ }^{\circ} \mathrm{n}_{\mathrm{MAX}}=15+7=22$.

The lowest possible mass peak is the $\mathrm{p}+6 \mathrm{H}$ peak ( $\mathrm{n}=0$ and $\mathrm{s}=0$ ). In that case, the $6 \mathrm{H}$ are due six protons that provide the $\mathrm{z}=6$ charge of the hexaprotonated ubiquitin. This would have been the only peak observed in the complete absence of salt impurities. In the present spectrum this peak is too small to be seen. The first visible peak in the $(n, 0)$ group is the

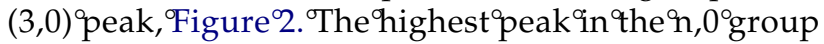
is for $\mathrm{n}=6$, where all charging protons are replaced by $\mathrm{Na}^{+}$ions. The replacement of the proton charges with $\mathrm{Na}^{+}$ions is expected because in the presence of high concentrations of $\mathrm{NaA}$ salt, the $\mathrm{Na}^{+}$ions become the dominant charges on the surface of the precursor droplets. This is due to an exchange of excess $\mathrm{H}_{3} \mathrm{O}^{+}$ ions at the droplet surface that was produced by the electrospray (see Introduction), with $\mathrm{Na}^{+}$ions from the $^{\circ}$ salt $^{\circ}$ solution. ${ }^{\circ}$ This $^{\circ}$ charge $^{\circ}$ replacement $^{\circ}$ and $^{\circ}$ its connection to the CRM was pointed out in earlier work $[10 \mathrm{a}] .{ }^{\circ}$ The ${ }^{\circ}{ }^{\circ}={ }^{\circ} 6^{\circ}$ peak, ${ }^{\circ}$ is ${ }^{\circ}$ of ${ }^{\circ}$ highest ${ }^{\circ}$ intensity ${ }^{\circ}$ for all $^{\circ}(\mathrm{n}, \mathrm{s})^{\circ}$ ions $^{\circ}$ in $^{\circ}$ Figure $^{\circ} 2 .^{\circ}$ The $^{\circ}$ highest $^{\circ} \mathrm{s}^{\circ}$ ion $^{\circ}$ group visible ${ }^{\circ}{ }^{\circ}$ Figure $2^{\circ}$ is $^{\circ} s^{\circ}={ }^{\circ} 5 .{ }^{\circ}$ However ${ }^{\circ}$ groups $s^{\circ}$ of ${ }^{\circ}$ peaks with $s=6,7,8$, etc. with decreasing intensities were observed at higher $\mathrm{m} / \mathrm{z}$ values.

The $^{\circ}$ mass $^{\circ}$ spectrum $^{\circ}$ shown $^{\circ}$ in $^{\circ}$ Figure $^{\circ} 3^{\circ}$ was $^{\circ}$ obtained under the same conditions except for the CAD* potential, which was increased from 160 to 450 $\mathrm{V}$. The high $\mathrm{CAD}^{*}$ leads to drastic changes. All groups with $s>0$ have disappeared and the $(n, 0)$ group has grown to much higher $\mathrm{n}$ values. The spacing between adjacent peaks remains equal to 22 mass units for the whole series of $(n, 0)$ peaks. Because the $\mathrm{NaI}$ adducts are replaced by $\mathrm{Na}-\mathrm{H}$ adducts, a loss of HI molecules must have occurred. The H must have been provided by the protein. The actual reactions that are probably involved are considered in the Results section on "Reaction mechanism leading to observed ions."

It is of interest to examine whether the $n, 0$ peaks do show a break off at higher mass. The high $\mathrm{m} / \mathrm{z}$ peaks in
Figure $^{\circ} 3^{\circ}$ are $^{\circ}$ shown $^{\circ}$ in $^{\circ}$ the ${ }^{\circ}$ extended $^{\circ}$ mass $^{\circ}$ spectrum, Figure ${ }^{\circ} 4$. The $^{\circ} \mathrm{n}, 0^{\circ}$ series $^{\circ}$ does $^{\circ}$ indicate ${ }^{\circ} a^{\circ}$ break $^{\circ}$ off $^{\circ}{ }^{\circ}{ }^{\circ} n^{\circ}=$ 18. Peaks with higher $m / z$ are not $n, 0$ peaks but $n, 1$ peaks with $n$ lower than $n=18$. The $n, 1$ peaks are probably the dissociation products of $n, s$ ions where $s$ was high. Such multiple NaI adduct ions require a large energy supply before they dissociate all the way down to $\mathrm{s}=0$.

\section{$\mathrm{NaCl}$}

Mass spectra of the $\mathrm{z}=6$ state obtained with $25 \mu \mathrm{M}$ ubiquitinand $19 \mathrm{mMNaCl}$ areshown in Figures $5-7$. The low $^{\circ} \mathrm{CAD}^{* \circ}={ }^{\circ} 160^{\circ} \mathrm{V}^{\circ}$ spectra, ${ }^{\circ}$ Figures $^{\circ} 5^{\circ}$ and ${ }^{\circ} 6$, ${ }^{\circ}$ are ${ }^{\circ}$ very different ${ }^{\circ}$ from ${ }^{\circ}$ the ${ }^{\circ}$ corresponding ${ }^{\circ} \mathrm{NaI}^{\circ}$ spectrum, ${ }^{\circ}$ Figure 2. The ${ }^{\circ} n, 0^{\circ}$ series ${ }^{\circ}$ does $^{\circ}$ not ${ }^{\circ}$ terminate ${ }^{\circ} t^{\circ} n^{\circ}={ }^{\circ} 6^{\circ}$ as ${ }^{\circ}$ was ${ }^{\circ}$ the case for $\mathrm{NaI}$ at low $\mathrm{CAD}^{*}$, but continues to higher $\mathrm{n}$ up to about $n=10$. The $n, s$ peaks $s>0$ are of very low intensity, ${ }^{\circ}$ see $^{\circ}$ Figure $^{\circ} 6$.

Application ${ }^{\circ}$ of $^{\circ}$ the ${ }^{\circ}$ high $^{\circ} \mathrm{CAD}^{* \circ}={ }^{\circ} 450^{\circ} \mathrm{V}$, ${ }^{\circ}$ Figure $^{\circ} 7$, leads to the disappearance of all $\mathrm{s}>0$ peaks and their replacement by $n, 0$ peaks, as was the case for NaI. For $\mathrm{NaCl}$ this replacement must occur by loss of $\mathrm{HCl}$.

The difference between the $\mathrm{NaI}$ and $\mathrm{NaCl}$ results indicates that the reactions leading to loss of $\mathrm{HI}$ require much more energy than those for the loss of $\mathrm{HCl}$. Thus for the $\mathrm{NaCl}$ case most of the loss of $\mathrm{HCl}$ from $\mathrm{s}>0$ ions has already occurred at the low $\mathrm{CAD}^{*}=160 \mathrm{~V}$ potential and increase of the $\mathrm{CAD}^{*}$ to $450 \mathrm{~V}$ leads to the additional loss of $\mathrm{HCl}$ from the remaining $\mathrm{s}>0$ ions.

It is notable that the $n, 0$ series terminates at $n=18$, Figure ${ }^{\circ},{ }^{\circ}$ as $^{\circ}$ was $^{\circ}$ also ${ }^{\circ}$ the ${ }^{\circ}$ case $^{\circ}$ when ${ }^{\circ} \mathrm{NaI}^{\circ}$ was $^{\circ}$ the ${ }^{\circ}$ added salt, ${ }^{\circ}$ Figure 4 .

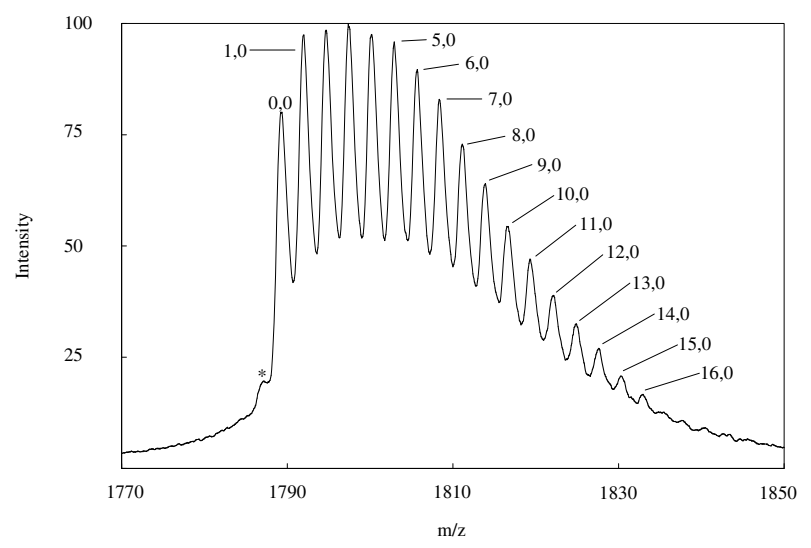

Figure 11. Spectrum of $\mathrm{z}=8$ charge state of $20 \mu \mathrm{M}$ lysozyme, 10 $\mathrm{mM} \mathrm{NaAc}$ at a high CAD of $450 \mathrm{~V}$. Lysozyme has 9 acidic groups

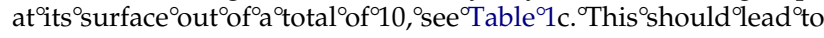
a break in the $n, 0$ series at $n=17$ or 18 . Unfortunately, because spectra could only be obtained under conditions favoring limited adduct formation, the break in sodiation falls short of the expected break at $\mathrm{n}=17$ or 18 . Peak indicated with an asterisk corresponds to $(0,0)$ lysozyme minus $\mathrm{H}_{2} \mathrm{O}$ or $\mathrm{NH}_{3}$. 


\section{Sodium Acetate NaAc}

Mass spectra (not shown) of the $\mathrm{z}=6$ state were obtained with the same concentrations as for $\mathrm{NaI}$ and $\mathrm{NaCl}$, i.e., $25 \mu \mathrm{M}$ ubiquitin and $1 \mathrm{mM} \mathrm{NaAc}$ at $\mathrm{CAD}^{*}$ 160 and $450 \mathrm{~V}$. These showed that the dissociation of $\mathrm{HAc}$ is even more facile than was the dissociation of $\mathrm{HCl}$ when $\mathrm{NaCl}$ was the salt used. The spectra at high $\mathrm{CAD}^{*}$ showed also a more distinct break of the $\mathrm{n}, 0$ ion series, at $\mathrm{n}=18$, then was the case with $\mathrm{NaI}$ and $\mathrm{NaCl}$.

The mass spectra obtained with ubiquitin and $\mathrm{NaAc}$ are $^{\circ}$ shown ${ }^{\circ}$ in ${ }^{\circ}$ Figure $^{\circ} 8,{ }^{\circ} 160^{\circ} \mathrm{V}^{\circ} \mathrm{CAD}^{\circ}$ and ${ }^{\circ}$ Figure $^{\circ} 9,{ }^{\circ} 375^{\circ} \mathrm{V}$ $\mathrm{CAD}$. These spectra were obtained with higher $\mathrm{NaAc}(5$ $\mathrm{mM}$ ) concentration and a larger spray tip diameter. A somewhat larger potential drop between the spray tip and the transfer capillary was used also. The current (52 $\mathrm{nA}$ ) observed is higher than the currents (33-36 nA) with $\mathrm{NaCl}$ and $\mathrm{NaI}$. The higher current indicates higher flow ${ }^{\circ}$ rates, ${ }^{\circ}$ see $^{\circ} \mathrm{Schmidt}^{\circ} \mathrm{et}^{\circ}$ al. ${ }^{\circ}[11 \mathrm{a}]$, and $^{\circ}$ the higher $^{\circ}$ flow rate leads to larger initial droplet diameters. Both the higher concentration and the bigger volume of the initial droplet are expected to lead to enhanced $\mathrm{NaAc}$ adduct formation as a result of the expected higher salt concentrations in the final droplet that contains the protein. ${ }^{\circ}$ The ${ }^{\circ}$ spectra, ${ }^{\circ}$ Figures ${ }^{\circ} 8^{\circ}$ and $^{\circ} 9,{ }^{\circ}$ do ${ }^{\circ}$ indicate ${ }^{\circ}$ that many more salt adducts were formed. Comparing the $\mathrm{NaCl}^{\circ}$ spectrum $^{\circ}$ Figure $^{\circ} 5^{\circ}$ with $^{\circ}$ the $^{\circ} \mathrm{NaAc}^{\circ}$ spectrum, Figure ${ }^{\circ},{ }^{\circ}$ one ${ }^{\circ}$ finds ${ }^{\circ}$ that ${ }^{\circ}$ the $e^{\circ}, 0^{\circ}$ peaks ${ }^{\circ}$ start $^{\circ}$ abruptly ${ }^{\circ}{ }^{\circ}$ ' $n$ $={ }^{\circ} 6,{ }^{\circ}$ Figure $^{\circ} 8,{ }^{\circ}$ while ${ }^{\circ}$ the ${ }^{\circ} \mathrm{n}, 0^{\circ}$ series $^{\circ}$ with ${ }^{\circ} \mathrm{NaCl}^{\circ}$ at $^{\circ}$ low concentration starts at $\mathrm{n}=0$ and slowly increases to $\mathrm{n}=$ 6. Thus, the proton charges are fully exchanged for $\mathrm{Na}^{+}$ charges at the high concentration conditions used for the ${ }^{\circ}$ Figure $^{\circ} 8$. ${ }^{\circ}$ The $^{\circ}$ intensity ${ }^{\circ}$ of ${ }^{\circ}$ the ${ }^{\circ} n, 0^{\circ}$ peaks ${ }^{\circ}$ with ${ }^{\circ} n^{\circ}>{ }^{\circ} 6$ is also much higher for $\mathrm{NaAc}$ than for $\mathrm{NaCl}$. This is evidence that many more $\mathrm{NaAc}$ ion pairs were available for adduct formation but also that the degree of dissociation of HA acid at $160 \mathrm{~V}$ was much higher with $\mathrm{NaAc}$ than was the case for $\mathrm{NaCl}$.

We conclude that the observed order of increasing $\mathrm{HA}$ dissociation is: $\mathrm{HAc}>\mathrm{HCl}>\mathrm{HI}$.

Notable also is the clear break of the $n, 0$ peaks past $n$ $={ }^{\circ} 18 .{ }^{\circ}$ The $^{\circ} 19,0^{\circ}$ and ${ }^{\circ}$ the $20,0^{\circ}$ peaks ${ }^{\circ}$ are $^{\circ}$ visible $^{\circ}$ in ${ }^{\circ}$ Figure 8 but have much lower intensities. The spectrum in Figure $^{\circ} 9^{\circ}$ where ${ }^{\circ}$ the ${ }^{\circ} \mathrm{CAD}^{* \circ}$ potential $^{\circ}$ is ${ }^{\circ} 375^{\circ} \mathrm{V}$, ${ }^{\circ}$ shows ${ }^{\circ} \mathrm{a}$ very much clearer break past 18,0.

The proposed reactions, between the ions and ion pairs provided by the salt and the residues as well as backbone functional groups of the protein, that lead to observed $^{\circ}$ spectra ${ }^{\circ}{ }^{\circ}{ }^{\circ}$ Figures ${ }^{\circ} 1-9^{\circ}$ are $^{\circ}$ discussed ${ }^{\circ}$ below.

\section{Reaction Mechanism leading to observed ions with salt additives $\mathrm{NaCl}, \mathrm{NaI}, \mathrm{NaAc}$, and $\mathrm{NH}_{4} \mathrm{Ac}$}

Before we consider the reactions that could be involved, we need to examine the state of the protein in the final charged droplet whose evaporation will lead to the charged protein. We do this with a greatly simplified model by assuming that all the equilibrium con- stants for ionization $\mathrm{K}_{\mathrm{A}}$ and $\mathrm{K}_{\mathrm{B}}$ are the same. First we examine the case where no salts are present in the solution. The basic and acidic residues of the protein are essentially completely ionized in the initial solution because of the low concentration of the protein. Consider a protein with 10 acidic and 12 basic residues at its surface. The $10 \mathrm{H}^{+}$and $10 \mathrm{OH}^{-}$ions produced by the ionization will recombine to $10 \mathrm{H}_{2} \mathrm{O}$ molecules because of the very low value of the ionization constant of water, $\mathrm{K}_{\mathrm{H} 2 \mathrm{O}}=\mathrm{K}_{\mathrm{W}} \times\left[\mathrm{H}_{2} \mathrm{O}\right]=$ $1.8^{\circ} \times{ }^{\circ} 10^{-96}$. ${ }^{\circ}$ The $^{\circ}$ two $^{\circ}$ excess $^{\circ} \mathrm{OH}^{\circ}$ ions ${ }^{\circ}$ will ${ }^{\circ}$ remain ${ }^{\circ}$ in solution. In the solution of the final droplet, the solute concentration has become very high because of the large loss of solvent by evaporation, and the two $\mathrm{OH}^{-}$ions are expected to recombine with two ionized basic residues or react with $\mathrm{H}^{+}$ions on the droplet surface. In either case, one can expect that some 10 acidic and 10 basic residues will remain ionized. This situation is expected to persist until complete dryness.

The assumption that a large number of ionized acidic and basic residues can remain ionized after practically all of the solvent has been removed by evaporation was first ${ }^{\circ}$ madein ${ }^{9}$ previous ${ }^{\circ}$ work $[10 \mathrm{c}]$, and ${ }^{\circ}$ was ${ }^{\text {based }}{ }^{\circ}$ on the argument presented above. Since then, we have found references in the protein literature that fully support the assumption of ionization persisting until essentially complete dryness. We quote two relevant recent references, ${ }^{\circ} \mathrm{Klibanov}^{\circ}[15]^{\circ}$ and $^{\circ}$ Sundd $^{\circ}$ et $^{\circ}$ al. $^{\circ}[16] .^{\circ}$ The $^{\circ}$ latter discuss salt bridges in ubiquitin crystals which are due to ${ }^{\circ}$ ionized ${ }^{\circ} \mathrm{Asp}^{\circ}$ and $^{\circ}$ Lys $^{\circ}$ interacting ${ }^{\circ}$ with $^{\circ}$ carboxylic groups.

The predicted presence of ionized basic and acidic residues on the proteins detected in ESI and NSI probably could be confirmed experimentally by techniques such $^{\circ}$ as $^{\circ}$ those $^{\circ}$ used $^{\circ}$ by $^{\circ}$ Stephenson ${ }^{\circ}$ and ${ }^{\circ}$ McLuckey ${ }^{\circ}[17$, 18]. ${ }^{\circ}$ However, ${ }^{\circ}$ one ${ }^{\circ}$ would ${ }^{\circ}$ have ${ }^{\circ}$ to ${ }^{\circ}$ produce ${ }^{\circ}$ the ${ }^{\circ}$ charged proteins, not with a solution that contains $1 \%$ HAc, but with protein solutions that contain no additives. The reasons for this restriction will become clear in the section on the "Difference between proteins."

On evaporation of the solvent from the charged final droplet, the excess $\mathrm{H}_{3} \mathrm{O}^{+}$ions on the surface of the droplet (see the Introduction) will add charges to the protein by either neutralizing some of the 10 ionized acidic residues, eq 3 , or by protonating the neutral basic residues, eq $4 \mathrm{a}$, or by protonating backbone amide (peptide) groups, eq $4 \mathrm{~b}$.

$$
\begin{aligned}
& \left(\mathrm{NH}_{3}^{+}-\left(\mathrm{CH}_{2}\right)_{4}-\mathrm{Prt}-\mathrm{CH}_{2} \mathrm{COO}^{-}\right)^{(\mathrm{z}-1)+}+\mathrm{H}_{3} \mathrm{O}^{+} \\
= & \left(\mathrm{NH}_{3}^{+}-\left(\mathrm{CH}_{2}\right)_{4}-\mathrm{Prt}-\mathrm{CH}_{2} \mathrm{COOH}\right)^{z+}+\mathrm{H}_{2} \mathrm{O} \\
& \left(\mathrm{NH}_{2}-\left(\mathrm{CH}_{2}\right)_{4}-\mathrm{Prt}-\mathrm{CH}_{2} \mathrm{COO}^{-}\right)^{(\mathrm{z}-1)+}+\mathrm{H}_{3} \mathrm{O}^{+} \\
= & \left(\mathrm{NH}_{3}^{+}-\left(\mathrm{CH}_{2}\right)_{4}-\mathrm{Prt}-\mathrm{CH}_{2} \mathrm{COO}^{-}\right)^{z+}+\mathrm{H}_{2} \mathrm{O} \\
& \left(\mathrm{NH}_{2}-\left(\mathrm{CH}_{2}\right)_{4}-\mathrm{Prt}-\mathrm{CH}_{2} \mathrm{COO}^{-}\right)^{(\mathrm{z}-1)+}+\mathrm{H}_{3} \mathrm{O}^{+} \\
= & \left(\mathrm{NH}_{2}-\left(\mathrm{CH}_{2}\right)_{4}-\mathrm{PrtH}-\mathrm{CH}_{2} \mathrm{COO}^{-}\right)^{z+}+\mathrm{H}_{2} \mathrm{O}
\end{aligned}
$$


Prt stands for the protein except for the two residues shown, which model lys and asp. The charge of the protein has increased by one unit and the mass of the protein has increased by one unit. Reaction 3 is expected to occur before reactions $4 \mathrm{a}$ and $4 \mathrm{~b}$ because of the large number of ionized acid residues available, and the much greater propensity of this ion pairing reaction to occur long before all the solvent has evaporated. The gas-phase basicities for $\mathrm{N}$-methyl acetamide $\mathrm{GB}=205.0$ $\mathrm{kcal} / \mathrm{mol}$ that models the peptide group is lower than that ${ }^{\circ}$ of ${ }^{\circ}$-butylamine ${ }^{\circ} \mathrm{GB}^{\circ}={ }^{\circ} 212^{\circ} \mathrm{kcal} / \mathrm{mol}^{\circ}[19]^{\circ}$ that models the basic residue lysine. However, there are many more backbone peptide groups on the surface of the protein than there are basic residues, so that reaction $4 \mathrm{~b}$ can effectively contribute to the charging. In any case, due to reactions 3 and 4 being protonations, a very clean and intense spectrum is expected and can be observed, ${ }^{\circ}$ see $^{\circ}$ Figure $^{\circ} 4 a^{\circ}$ in $[10 \mathrm{c}],{ }^{\circ}$ under ${ }^{\circ}$ the ${ }^{\circ}$ condition where ${ }^{\circ}$ no salt additive is used. The protein will also retain several ionized basic and several ionized acidic residues at its surface.

Ubiquitin has 12 acidic sites; this includes the Cterminal acid and 13 basic residues at its surface, ${ }^{\circ}$ see Table $^{\circ} 1 .^{\circ}$ According ${ }^{\circ}$ to the scheme above, ubiquitin, when in the final droplet, will have some 12 ionized acidic and 12 ionized basic residues at its surface. After charging to $\mathrm{z}=6$ by excess $\mathrm{H}_{3} \mathrm{O}^{+}$ions, ubiquitin will have approximately 6 neutralized acidic, 6 ionized acidic, and 12 ionized basic residues, as well as one basic residue that is neutralized because of recombina-

Table 1. Relevant protein data

Table 1a: Ubiquitin, ExPASy code UBIQ_ BOVIN, MW 8564.84

\begin{tabular}{|c|c|c|c|c|c|}
\hline \multicolumn{5}{|c|}{ Acidic Groups ${ }^{\text {b }}$} & Basic Groups ${ }^{\mathrm{c}}$ \\
\hline $\begin{array}{c}\text { Total } \\
12\end{array}$ & $\begin{array}{l}\text { Surface (X-ray, IUBQ.pdb) de } \\
12 \\
\text { Asp21, Asp32, Asp39, Asp52, } \\
\text { Asp58, Glu16, Glu18, Glu24, } \\
\text { Glu34, Glu51, Glu64, Gly76 }\end{array}$ & & $\begin{array}{c}\text { Not on Surface } \\
0\end{array}$ & & $\begin{array}{c}\text { Total } \\
13\end{array}$ \\
\hline \multicolumn{6}{|c|}{ Table 1b: Cytochrome $c$, N-acetylated, ExPASy code CYC_HORSE, MW 12360.05 } \\
\hline \multicolumn{4}{|c|}{ Acidic Groups ${ }^{\mathrm{b}}$} & & Basic Groups ${ }^{c}$ \\
\hline Total & $\begin{array}{l}\text { Surface }^{e} \\
\text { (H-NMR, 1AKK.pdb) }^{f}\end{array}$ & Not on Surface & $\begin{array}{l}\text { Surface }^{e} \\
\quad(X-r a y, 1 H R C . p d b)\end{array}$ & Not on Surface & Total \\
\hline 15 & $\begin{array}{l}\text { Asp2, Asp50, } \\
\text { Asp93, Glu4, } \\
\text { Glu21, Glu61, } \\
\text { Glu62, Glu66, } \\
\text { Glu69, Glu92, } \\
\text { Glu104, Glu104, } \\
\text { heme-CO2H(1) }\end{array}$ & Glu90, heme-CO2H(2) & $\begin{array}{l}13 \\
\text { Asp2, Asp50, } \\
\text { Asp93, Glu4, } \\
\text { Glu21, Glu61, } \\
\text { Glu62, Glu66, } \\
\text { Glu69, Glu90, } \\
\text { Glu92, Glu104, } \\
\text { Glu104 }\end{array}$ & $\begin{array}{l}\quad 2 \\
\text { heme- } \\
\mathrm{CO} 2 \mathrm{H}(1) \text {, } \\
\text { heme- } \\
\mathrm{CO} 2 \mathrm{H}(2)\end{array}$ & 24 \\
\hline
\end{tabular}

Table 1c: Lysozyme, ExPASy code LYC CHICK, MW 14305.08 ${ }^{a}$

\begin{tabular}{lllll}
\hline \hline Acidic Groups $^{\mathrm{b}}$ & & & Basic Groups $^{\mathrm{c}}$ \\
\hline \hline Total & $\begin{array}{l}\text { Surface } \\
\text { (Neutron diffraction, }\end{array}$ & Not on Surface & $\begin{array}{l}\text { Surface } \\
\text { (X-ray, 1LSF.pdb) }\end{array}$ & Not on Surface \\
& 1LZN.pdb) & & 9 & 1 \\
10 & 9 & 1 & Asp18, Asp48, & Asp66 \\
& Asp18, Asp48, & Asp66 & Asp52, Asp87, & \\
Asp52, Asp87, & & Asp101, Asp119 & \\
Asp101, Asp119 & & Glu7, Glu35, & \\
Glu7, Glu35, & & Leu129 & \\
& & &
\end{tabular}

aAverage MW from Swiss-Prot database, www.expasy.org. The database calculates the fully reduced form of the peptide sequence without sulfide bridges, heme groups or other modifications. Cytochrome $c$ (Table $1 \mathrm{~b}$ ) has an additional $\mathrm{N}$-acetyl group (43.02- $\mathrm{H}$ for the $\mathrm{N}$ terminal attachment) and a heme group (616.49, covalently bound using the ethylene bridges to Cys14 and Cys17) that need to be added to the fully reduced sequence (11701.55). The calculated average MW assumes the heme iron to be +2 . Lysozyme (Table 1c) has four disulfide bridges, so that $8 \mathrm{H}$ has to be subtracted from the calculated fully reduced sequence (14313.14), after removal of the signal peptide sequence 1-18 from the Lysozyme precursor. bEach C-terminal adds a single acidic group, except for the Cytochrome $c$ (Table 1b) Glu104, which adds two acidic groups. The heme group of Cytochrome c adds two acidic groups.

'Each N-terminal adds a single basic group, except for Cytochrome $c$ (Table 1b), which is N-acetylated. For Ubiquitin and Lysozyme all basic groups are on the surface. For Cytochrome $c$ (Table 1b) the H-NMR structure indicates all groups are on the surface, the X-ray structure indicates His18 is not on the surface.

d1UBQ.pdb is the human Ubiquitin monomer of the same sequence and structure as the bovine Ubiquitin dimer, 1AAR.pdb.

${ }^{e}$ Acidic groups that engage in $\mathrm{H}$ bonding to adjacent basic groups are indicated in boldface. The position of the acidic and basic groups was determined using RasMol version 2.7.2.1 (April 2001), see www.umass.edu/microbio/rasmol and the ExPASy pdb files indicated in the table.

fThe Cytochrome $c$ used for the H-NMR structure was not N-acetylated. 
tion of the 13th ionized basic site with the one excess $\mathrm{OH}^{-}$counter ion.

In the presence of salts such as $\mathrm{NaCl}$ in the solution, one again expects that the ion pairing reactions, where $\mathrm{Na}^{+}$recombines with ionized acidic residues and $\mathrm{Cl}^{-}$ with the ionized basic residues, will occur preferentially. Addition of $\mathrm{Na}^{+}$only leads to charging, see eq 5 , while addition of $\mathrm{Na}^{+}$and $\mathrm{Cl}^{-}$in two successive reactions leads to no change of the charge, eq 6. However, $\mathrm{Na}^{+}$can also form a relatively strong bond with a backbone peptide -CO-NH- group, eq 7.

$$
\begin{aligned}
& \left(\mathrm{NH}_{3}^{+}-\left(\mathrm{CH}_{2}\right)_{4}-\mathrm{Prt}-\mathrm{CH}_{2} \mathrm{COO}^{-}\right)^{(\mathrm{z}-1)+}+\mathrm{Na}^{+} \\
= & \left(\mathrm{NH}_{3}^{+}-\left(\mathrm{CH}_{2}\right)_{4}-\mathrm{Prt}-\mathrm{CH}_{2} \mathrm{COONa}\right)^{\mathrm{z}+} \\
& \left(\mathrm{NH}_{3}^{+}-\left(\mathrm{CH}_{2}\right)_{4}-\mathrm{Prt}-\mathrm{CH}_{2} \mathrm{COO}^{-}\right)^{(\mathrm{z}-1)+}+\mathrm{Na}^{+} \\
+ & \mathrm{Cl}^{-}=\left(\mathrm{ClNH}_{3}-\left(\mathrm{CH}_{2}\right)_{4}-\mathrm{Prt}-\mathrm{CH}_{2} \mathrm{COONa}\right)^{(\mathrm{z}-1)+}
\end{aligned}
$$

$$
\begin{aligned}
& \left(\mathrm{NH}_{3}^{+}-\left(\mathrm{CH}_{2}\right)_{4}-\mathrm{Prt}-\mathrm{CH}_{2} \mathrm{COO}^{-}\right)^{(\mathrm{z}-1)+}+\mathrm{Na}^{+} \\
= & \left(\mathrm{NH}_{3}^{+}-\left(\mathrm{CH}_{2}\right)_{4}-\mathrm{PrtNa}-\mathrm{CH}_{2} \mathrm{COO}^{-}\right)^{\mathrm{z}+}
\end{aligned}
$$

The $\mathrm{Na}^{+}$bond energy to the peptide group modeled by the interaction of $\mathrm{Na}^{+}$with $\mathrm{N}$-methyl acetamide has been ${ }^{\circ}$ determined ${ }^{\circ} \mathrm{as}^{\circ} 36^{\circ} \mathrm{kcal} / \mathrm{mol}^{\circ}[20]^{\circ}{ }^{\circ}$ More $^{\circ}$ recently, Wesdemiotis ${ }^{\circ}$ and $^{\circ}$ coworkers $^{\circ}[21]^{\circ}$ have $^{\circ}$ determined ${ }^{\circ}$ the binding energies of $\mathrm{Na}^{+}$complexes with a number of amino acids and small peptides. With some of these peptides, multiple coordination of $\mathrm{Na}^{+}$can be present. The bond energies in such cases are above $40 \mathrm{kcal} / \mathrm{mol}$. Thus, the single and multiple coordination bond energies are high enough to prevent loss of $\mathrm{Na}^{+}$from backbone peptide groups in the heated transfer capillary and in the $\mathrm{CAD}^{*}$ stage.

We propose that reactions 5-7 followed by sufficiently energetic $\mathrm{CAD}^{*}$ are responsible for the generation of the series of high intensity $n, 0$ ions from 1,0 to 18,0 ; see section on "Ubiquitin, $\mathrm{NaCl}, \mathrm{NaI}$ and $\mathrm{NaAc}$ etate ${ }^{\circ}$ adducts, ${ }^{\circ}$ and ${ }^{\circ}$ Figures $4, \%$, ${ }^{\circ}$ and 9 . The ${ }^{\circ}$ origin ${ }^{\circ}$ of $n, 0$

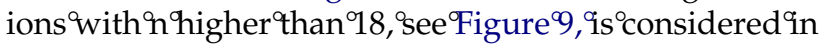
the section on "A mechanism leading to NaA adducts."

As noted before, a loss of acid HA, where $\mathrm{A}=\mathrm{Cl}$ or I or Ac, driven by $C A D^{*}$, must occur for the full $n, 0$ series up to $\mathrm{n}=18$ to be observed. With the proposed reaction mechanism, eqs 5-7, the loss of $\mathrm{HA}$, in this case $\mathrm{HCl}$, should occur by reaction 8 involving the reactant, $\left(\mathrm{ClNH}_{3}-\left(\mathrm{CH}_{2}\right)_{4}-\mathrm{Prt}-\mathrm{CH}_{2} \mathrm{COONa}\right)^{(\mathrm{z}-1)+}$ that was produced by reaction 6 .

$$
\begin{aligned}
& \left(\mathrm{ClH}_{3} \mathrm{~N}-\left(\mathrm{CH}_{2}\right)_{4}-\mathrm{Prt}-\mathrm{CH}_{2} \mathrm{COONa}\right)^{(\mathrm{z}-1)+} \\
= & \mathrm{HCl}+\left(\mathrm{H}_{2} \mathrm{~N}-\left(\mathrm{CH}_{2}\right)_{4}-\mathrm{Prt}-\mathrm{CH}_{2} \mathrm{COONa}\right)^{(\mathrm{z}-1)+}
\end{aligned}
$$

Reaction 8 is endothermic and occurs either in the heated capillary or/and in the CAD* stage. The activation energies for the reaction are small, less than 20 $\mathrm{kcal} / \mathrm{mol}$ and allow this dissociation even at low CAD*.
The expected activation energies for the dissociation of $\mathrm{HA}$ are discussed in the section on "Reasons for observed differences," and "The dissociation energy of ammonium acetate."

Because ubiquitin has some 12 ionized acidic and 13 ionized basic sites, it can accommodate $12 \mathrm{Na}^{+}$and $12 \mathrm{Cl}^{-}{ }^{\circ}$ ions by ${ }^{\circ}$ reaction $\%$. The 13 th ${ }^{\circ}$ ionized basic ${ }^{\circ}$ site ${ }^{\circ}$ will pick up the one excess negative ion in the solution. Due to the preponderance of $\mathrm{Cl}^{-}$ions over $\mathrm{OH}^{-}$ions, the excess ion picked up will be $\mathrm{Cl}^{-}$. When the charge state is $\mathrm{z}=+6$, and all the charges are due to $\mathrm{Na}^{+}$, an excess of $6 \mathrm{Na}^{+}$by a reaction analogous to 7 is required. After 13 HA were lost by reaction 8 , the resulting intense $n, 0$ ion series for this charge state will terminate at 18,0 because of the $12 \mathrm{Na}$ on the 12 acidic sites and the $6 \mathrm{Na}^{+}$ charges. This is the value observed in the spectra shown in $^{\circ}$ the ${ }^{\circ}$ preceding $^{\circ}$ section, ${ }^{\circ}$ see $^{\circ}$ Figure $^{\circ} 4,,^{\circ} 7,{ }^{\circ}$ and ${ }^{\circ} 9 .^{\circ}$ A higher charge state such as $\mathrm{z}=7$ will have seven $\mathrm{Na}^{+}$ charging ions and a series that terminates at 19,0. This value was observed experimentally with $\mathrm{NaAc}$ ( mass spectrum not shown).

The above findings can be generalized: The ion with the highest mass in the intense $n, 0$ series has an $n_{\operatorname{MAX}}$ that equals the number of acidic residues, Nacid, at the surface of the protein plus the number of charges $\mathrm{z}$.

$$
\mathrm{n}_{\mathrm{MAX}}=\text { Nacid }^{\circ}+\mathrm{Z}^{\circ}
$$

Thus, ${ }^{\circ}$ apparently ${ }^{\circ}$ one $^{\circ}$ can $^{\circ}$ determine ${ }^{\circ} \mathrm{Nacid}^{\circ}$ at $^{\circ}$ the ${ }^{\circ}$ surface of an unknown protein by determining $\mathrm{n}_{\mathrm{MAX}}$ and $\mathrm{z}$ from a spectrum of the protein using a sodium salt additive like sodium acetate under conditions that lead to addition of a sufficiently large number of salt ion pairs to the protein. Results for the proteins cytochrome $c$ and lysozyme are given in the section on "Results with sodium acetate and other proteins." These results show that the determination based on eq 9 is not always possible.

Gross $^{\circ}$ and $^{\circ}$ coworkers $^{\circ}[22]^{\circ}$ have $^{\circ}$ reported $^{\circ}$ that $^{\circ} \mathrm{eq}^{\circ} 9$ holds for oligopeptides that were sprayed from a solution containing Na salts. Earlier work by Neubauer and Anderegg $\left[1\right.$ 1a ${ }^{\circ}$ also ${ }^{\circ}$ reports ${ }^{\circ}$ observations that ${ }^{\circ}$ are ${ }^{\circ}$ similar to ${ }^{9}$ hose ${ }^{\text {by }}{ }^{\circ} \mathrm{Gross}^{\circ} \mathrm{et}^{\circ} \mathrm{al}^{\circ}$ [22]. ${ }^{\circ}$ Because ${ }^{\circ}$ oligopeptides have open structures, all acidic residues, including the terminal carboxylic group, are available for sodiation. The authors ${ }^{\circ}[22]^{\circ} \operatorname{did}^{\circ}$ not $^{\circ}$ attempt ${ }^{\circ}$ to ${ }^{\circ}$ rationalize ${ }^{\circ}$ the ${ }^{\circ}$ rule ${ }^{\circ}$ on the basis of the electrospray mechanism and reactions that could lead to the observed ions. A mechanism that is analogous to that proposed for the proteins can be given. Some of the peptides used were very small and one $^{\circ}$ expects $^{\circ}$ that $^{\circ}$ the $^{\circ}$ ion $^{\circ}$ evaporation ${ }^{\circ}$ model $^{\circ}(\text { IEM })^{\circ}[23$, $24]^{\circ}$ holds $^{\circ}$ for ${ }^{\circ}$ them $^{\circ}$ and $^{\circ}$ probably $^{\circ}$ also ${ }^{\circ}$ for ${ }^{\circ}$ the ${ }^{\circ}$ larger oligopeptides. According to IEM the ions, instead of staying in the evaporating droplet until the droplet evaporates completely as is the case for CRM, escape form the droplet by "ion evaporation" at an earlier stage. The escape takes place only after the droplets have become very small (droplet diameter in the 8-10 nm $^{\circ}$ range $)^{\circ}[24] .^{\circ}$ Therefore, ${ }^{\circ}$ these ${ }^{\circ}$ droplets ${ }^{\circ}$ have $^{\circ}$ experi- 
enced extensive solvent evaporation and the concomitant very large increase of concentration of all solutes in the ${ }^{\circ}$ droplet [7]. The high ${ }^{\circ}$ concentration ${ }^{\circ}$ will ${ }^{\circ}$ promoteion pairing between the ions present in the solution and result in reactions analogous to eqs 5 and 6 but involving the peptides rather than the protein. On escape from the droplet, the peptide will acquire charge from the surface of the droplets and when a sodium salt was used, that charge will be mostly due to $\mathrm{Na}^{+}$ions. Those peptides that have all their acidic residues sodiated will have to acquire the charge by reacting with surface charges, i.e., $\mathrm{Na}^{+}$ions. The $\mathrm{Na}^{+}$acceptors are expected to be the amide CO-NH- groups of the peptide. This reaction is analogous to reaction 7. Any ionized basic residues and the terminal amino group that have ion paired with a $\mathrm{Cl}^{-}$ion will have to lose $\mathrm{HCl}$ in the clean up process-a reaction analogous to eq 8 .

An example of the proposed reactions is given below for the dipeptide Gly-Asp; eq 10 represents the ion pairing that occurs in the solution of the very small droplet with high $\mathrm{NaCl}$ concentration. Charging occurs with excess $\mathrm{Na}^{+}$ions at the surface of the droplet, eq 11:

$$
\begin{aligned}
& \mathrm{NH}_{3}^{+}-\mathrm{CH}_{2}-\mathrm{CO}-\mathrm{NH}-\mathrm{CH}\left(\mathrm{CH}_{2} \mathrm{CO}_{2}^{-}\right)-\mathrm{CO}_{2}^{-} \\
+ & 2 \mathrm{Na}^{+}+2 \mathrm{Cl}^{-}=\mathrm{NH}_{3} \mathrm{Cl}-\mathrm{CH}_{2}-\mathrm{CO}-\mathrm{NH} \\
- & \mathrm{CH}\left(\mathrm{CH}_{2} \mathrm{CO}_{2} \mathrm{Na}\right)-\mathrm{CO}_{2} \mathrm{Na}+\mathrm{Cl}^{-} \\
& \mathrm{NH}_{3} \mathrm{Cl}-\mathrm{CH}_{2}-\mathrm{CO}-\mathrm{NH}-\mathrm{CH}\left(\mathrm{CH}_{2} \mathrm{CO}_{2} \mathrm{Na}\right) \\
- & \mathrm{CO}_{2} \mathrm{Na}+\mathrm{Na}^{+}=\mathrm{NH}_{3} \mathrm{Cl}-\mathrm{CH}_{2}-\mathrm{CONa}^{+}-\mathrm{NH} \\
- & \mathrm{CH}\left(\mathrm{CH}_{2} \mathrm{CO}_{2} \mathrm{Na}\right)-\mathrm{CO}_{2} \mathrm{Na}
\end{aligned}
$$

$\mathrm{HCl}$ is lost in the cleanup stage, as mentioned above. The total process leads to the observation in the mass spectrum of a singly charged ion that is tri-sodiated. Each sodium has increased the mass by 22 mass units relative to the singly charged protonated peptide ion observed under conventional (protonating) conditions, such as in the presence of acetic acid or ammonium acetate.

Reasons for Observed Differences in Mass Spectra When the Different Salts $\mathrm{NaCl}, \mathrm{NaI}$, and $\mathrm{NaAc}$ are Used

It was observed in the section on "Ubiquitin, $\mathrm{NaCl}, \mathrm{NaI}$, NaAcetate adducts," that the tendency for the loss of $\mathrm{HA}$ with $\mathrm{CAD}^{*}$ of ubiquitin with salt adducts $\mathrm{NaA}$ increases in the order $\mathrm{A}=\mathrm{I}<\mathrm{Cl}<\mathrm{Ac}$. This order can be rationalized on the basis of reaction $8 \mathrm{a}$, which analogous to reaction 8 .

$$
\begin{aligned}
& \left(\mathrm{AH}_{3} \mathrm{~N}-\left(\mathrm{CH}_{2}\right)_{4}-\mathrm{Prt}-\mathrm{CH}_{2} \mathrm{COONa}\right)^{(\mathrm{z}-1)+} \\
= & \mathrm{HA}+\left(\mathrm{H}_{2} \mathrm{~N}-\left(\mathrm{CH}_{2}\right)_{4}-\mathrm{Prt}-\mathrm{CH}_{2} \mathrm{COONa}\right)^{(\mathrm{z}-1)+}
\end{aligned}
$$

Because the basic residue remains the same while the $\mathrm{A}^{-}$changes, the dissociation will depend on some property of $\mathrm{A}^{-}$or $\mathrm{AH}$. Thus, if $\mathrm{AH}$ is a very strong acid, i.e., a very good proton donor, the reactant will be stabilized by an ion pair type (Coulomb attraction) bonding, while a weak acid will stabilize the product $\mathrm{AH}$ of reaction $8 \mathrm{a}$. Determinations of the gas-phase acidities ${ }^{\circ}[25]^{\circ}$ show $^{\circ}$ that ${ }^{\circ}$ the ${ }^{\circ}$ free-energy ${ }^{\circ} \Delta \mathrm{G}^{\circ}$ at $300 \mathrm{~K}$ for the reaction, $\mathrm{HA}=\mathrm{A}^{-}+\mathrm{H}^{+}$, is lowest for $\mathrm{HI}$ and highest for $\mathrm{AcH}$. The actual values in $\mathrm{kcal} / \mathrm{mol}$ are: 309 $(\mathrm{HI}), 328(\mathrm{HCl})$, and $341(\mathrm{HAc})$. These are large differences. Therefore, the strongest acid $\mathrm{HI}$ will lead to the largest stabilization of the adduct: $\left(\mathrm{AH}_{3} \mathrm{~N}-\left(\mathrm{CH}_{2}\right)_{4}\right.$-Prt$\left.\mathrm{CH}_{2} \mathrm{COONa}\right)^{(\mathrm{z}-1)+}$ and thus also to the lowest rate of the decomposition reaction 8a. The agreement of the predicted order with the order observed provides support for the proposed reaction mechanism, eqs 3-8.

\section{Differences Between Proteins Produced from} Solutions that Have No Additives and Proteins Produced with $\mathrm{NH}_{4}$ Ac or Acetic Acid as Additive

The replacement of alkali ions such as $\mathrm{Na}^{+}$with ammonium ions such as $\mathrm{NH}_{4}^{+}$has important consequences. The use of the ammonium acetate as salt additive is a standard practice in protein mass spectrometry because it leads to very clean spectra in which the multiply charge on the proteins is essentially completely due to protons. This beneficial effect of ammonium acetate was discovered by trial and error. Ammonium acetate acts as a buffer (even though a very weak one) and that is an advantage when nondenatured proteins are to be obtained. What is not generally recognized is that ammonium acetate leads to adducts to the protein that are analogous to those discussed in the previous sections. However, these adducts, unlike the alkali ion adducts, are very easily removed in the clean up process so that clean spectra are observed. The ammonium ions form an ion pair adduct with the ionized acidic sites on the surface of the protein while the acetate anion does the same with the ionized basic sites leading to the product, eq 12a. Both of these adducts dissociate readily (see section on "The dissociation energy of ammonium acetate") in the clean up stages, eq $12 \mathrm{~b}$ :

$$
\begin{aligned}
& \mathrm{Ac}^{-}+\mathrm{NH}_{4}^{+}+\left(\mathrm{NH}_{3}^{+}-\left(\mathrm{CH}_{2}\right)_{4}-\mathrm{Prt}\right. \\
- & \left.\mathrm{CH}_{2} \mathrm{COO}^{-}\right)^{(\mathrm{z}-1)+}=\left(\mathrm{AcH}_{3} \mathrm{~N}-\left(\mathrm{CH}_{2}\right)_{4}-\mathrm{Prt}\right. \\
- & \left.\mathrm{CH}_{2} \mathrm{COONH}_{4}\right)^{(\mathrm{z}-1)+} \\
& \left(\mathrm{AcH}_{3} \mathrm{~N}-\left(\mathrm{CH}_{2}\right)_{4}-\mathrm{Prt}-\mathrm{CH}_{2} \mathrm{COONH}_{4}\right)^{(\mathrm{z}-1)+} \\
= & \mathrm{AcH}+\left(\mathrm{H}_{2} \mathrm{~N}-\left(\mathrm{CH}_{2}\right)_{4}-\mathrm{Prt}-\mathrm{CH}_{2} \mathrm{COOH}\right)^{(\mathrm{z}-1)+} \\
+ & \mathrm{NH}_{3}
\end{aligned}
$$

Note that the ionized acidic and basic sites are now neutralized. The charging of the protein by $\mathrm{NH}_{4}^{+}$ions occurs via reactions analogous to eqs $4 \mathrm{a}$ and $4 \mathrm{~b}$ for charging by $\mathrm{H}_{3} \mathrm{O}^{+}$. 


$$
\begin{aligned}
& \left(\mathrm{NH}_{2}-\left(\mathrm{CH}_{2}\right)_{4}-\mathrm{Prt}-\mathrm{CH}_{2} \mathrm{COO}^{-}\right)^{(\mathrm{z}-1)+}+\mathrm{NH}_{4}^{+} \\
= & \left(\mathrm{NH}_{3}^{+}-\left(\mathrm{CH}_{2}\right)_{4}-\mathrm{Prt}-\mathrm{CH}_{2} \mathrm{COO}^{-}\right)^{\mathrm{z}+}+\mathrm{NH}_{3} \\
& \left(\mathrm{NH}_{2^{\circ}}-\left(\mathrm{CH}_{2}\right)_{4}-\mathrm{Prt}-\mathrm{CH}_{2} \mathrm{COO}^{-}\right)^{(\mathrm{z}-1)+}+\mathrm{NH}_{4}^{+} \\
= & \left(\mathrm{NH}_{2}-\left(\mathrm{CH}_{2}\right)_{4}-\mathrm{PrtH}-\mathrm{CH}_{2} \mathrm{COO}^{-}\right)^{\mathrm{z}+}+\mathrm{NH}_{3}(1
\end{aligned}
$$

Reaction 13a will occur when the protein has more basic sites than acidic sites at its surface, which can lead to the presence of basic sites that are not ionized. The proton transfer reaction from $\mathrm{NH}_{4}^{+}$to ${ }^{\circ}$ the ${ }^{\circ}$ peptide ${ }^{\circ}$ group, ${ }^{\circ} \mathrm{eq}$ $13 \mathrm{~b}$, is expected to proceed readily because the gasphase basicity of $\mathrm{N}$ - methyl acetamide (GB: $205 \mathrm{kcal} /$ mol $^{\circ}[19],{ }^{\circ}$ which ${ }^{\circ}$ models ${ }^{\circ}$ the ${ }^{\circ}$ peptide ${ }^{\circ}$ group,${ }^{\circ}$ is ${ }^{\circ}$ higher than ${ }^{\circ}$ that ${ }^{\circ}$ of $^{\circ}$ ammonia $^{\circ}\left(\mathrm{GB}:{ }^{\circ} 197.5^{\circ} \mathrm{kcal} / \mathrm{mol}^{\circ}[19]^{\circ}\right.$ Reactions 13a and 13b include the dissociation of $\mathrm{NH}_{3}$ that is expected to occur in the clean up stages. Theoretical ab initio calculations provided in the section "The dissociation energy of ammonium acetate," lead to predictions that the dissociation will have activation energies that are less than $15 \mathrm{kcal} / \mathrm{mol}$, so that a very facile dissociation is expected.

It should be noted that the proton on the peptide group need not stay on that group. There is very good

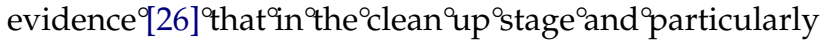
at high CAD potentials, proton migration to different basic sites can occur. Thus, the proton may transfer from the peptide group to a basic residue that had previously lost $\mathrm{AcH}$, by reaction $12 \mathrm{~b}$. Such proton migration may lead to a distribution of the protons to the sites that have the highest apparent gas-phase basicities.

Also of interest are experiments where $1 \%$ acetic acid is used as additive to the protein solution. Proteins such as ubiquitin remain essentially folded when produced from such $^{\circ}$ solutions ${ }^{\circ}[4] .{ }^{\circ}$ The $^{\circ}$ acetic $^{\circ}$ acid $^{\circ}$ additive ${ }^{\circ}$ is ${ }^{\circ}$ routinely

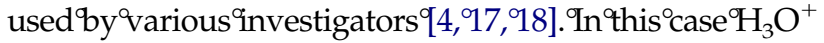
will go to the binding sites discussed above for $\mathrm{NH}_{4}^{+}$, see eq 12. In both of these modes of production, the charged proteins in the gas-phase will have no ionized acidic or basic sites left in contradistinction to proteins produced in the absence of additives.

Recently, ${ }^{\circ}$ Iavarone ${ }^{\circ} \mathrm{et}^{\circ}{ }^{\circ} \mathrm{l}^{\circ}{ }^{\circ}[1 \mathrm{~h}]^{\circ}{ }^{\circ}$ have $\mathrm{o}^{\circ}$ shown ${ }^{\circ}$ that ${ }^{\circ}$ the use of ammonium acetate at large concentrations is beneficial in cleaning up protein spectra that exhibit unwanted cationization due to sodium or other metal salt impurities. These results can be rationalized on the basis of the reaction schemes proposed in the present work. When the concentration of $\mathrm{NH}_{4}^{+}$dominates in the solution over the impurity $\mathrm{Na}^{+}$ions, the charging via eq 5 will be replaced by charging by $\mathrm{NH}_{4}^{+}$, eq 13. Similarly, the salt adduct forming eq 6 will by replaced by eq 12 and a very clean, protonated mass spectrum will result.

\section{A Mechanism Leading to NaA Adducts to Ubiquitin that Result in $n, 0$ Values Beyond $n=18$}

In the section, "Ubiquitin, $\mathrm{CaCl}, \mathrm{NaI}, \mathrm{NaAcetate}$ adducts," it was observed that although the n,0 series at high CAD potentials remains with high intensity up to $\mathrm{n}_{\mathrm{MAX}}=18$, there are very low intensity $\mathrm{n}, 0$ peaks above $\mathrm{n}=18$. This group of peaks can be made more visible by working at higher currents and/or NaAc concentrations ${ }^{\circ}$ as ${ }^{\circ}$ is $^{\circ}$ the ${ }^{\circ}$ case $^{\circ}$ in ${ }^{\circ}$ Figure ${ }^{\circ} 9^{\circ}$ that ${ }^{\circ}$ was $^{\circ}$ obtained ${ }^{\circ}$ with $^{\circ}{ }^{\circ}$ $\mathrm{mM} \mathrm{NaAc}$ and a current of $52 \mathrm{nA}$. Similar observations were $^{\circ}$ made $^{\circ}$ by $^{\circ}$ other ${ }^{\circ}$ groups $^{\circ}\left[1-3,{ }^{\circ} 22\right]^{\circ}$ working ${ }^{\circ}$ with peptides or proteins. What is the origin of these peaks?

Siu and ${ }^{\circ}$ coworkers ${ }^{\circ}[1 b, 1 c]$ have ${ }^{\circ}$ published ${ }^{\circ}$ a reaction mechanism that could explain the origin of these peaks. Using formamide, $\mathrm{HCONH}_{2}$, as a model for the peptide group and $\mathrm{NaCl}$ as the reactant, the numerical data for the relative free-energy values (in $\mathrm{kcal} / \mathrm{mol}$ ) shown below were obtained using DFT calculations B3LYP/ $6311^{\circ}++^{\circ} \mathrm{G}^{\circ}(\mathrm{d}, \mathrm{p})^{\circ}[1 \mathrm{c}] .{ }^{\circ}{ }^{\circ}$ The ${ }^{\circ}$ notation ${ }^{\circ}$ used $^{\circ}$ for ${ }^{\circ}$ the ${ }^{\circ}$ reactants R2, Complex M4, and Products P2 is also used below to facilitate comparison with the original data given ${ }^{\circ}{ }^{\circ}{ }^{\circ}$ igures $^{\circ} 3^{\circ}$ and ${ }^{\circ} 4,{ }^{\circ}$ reference ${ }^{\circ}[1 \mathrm{c}]$.

For actual structures of the transition states, see Figure $4 b,[1 c]$.

$$
=\underset{\mathrm{R} 2=16.4}{\mathrm{HCONH}}+\mathrm{NaCl}=\underset{\mathrm{M} 4=0.0}{\mathrm{HCONaClNH}} \mathrm{H}_{2}
$$

We assume that the complex modeled by M4 was formed by addition of $\mathrm{NaCl}$ ion pairs to the amide groups of the protein backbone. In the last stages of droplet evaporation, abundant formation of $\mathrm{NaCl}$ ion pairs is expected. The complex M4 can be expected to survive low $\mathrm{CAD}^{*}$ potentials. At high $\mathrm{CAD}^{*}$, dissociation to R2 which requires only $16.4 \mathrm{kcal} / \mathrm{mol}$ will be dominant but some small yield of $\mathrm{HCl}$ via channel to $\mathrm{P} 2$ could also occur. The low intensity of the $n, 0$ ions with $\mathrm{n}^{\circ}>^{\circ} 18^{\circ}$ observed $^{\circ}$ in $^{\circ}$ the $^{\circ}$ mass $^{\circ}$ spectra $^{\circ}$ such $^{\circ}$ as $^{\circ}$ Figure $^{\circ} 9$ may be, at least in part, a consequence of the expected inefficiency of the channel leading to $\mathrm{HCl}$ in eq 14.

The authors $\left[1 \mathrm{~b},{ }^{\circ} 1 \mathrm{c}\right]^{\circ}$ assumed ${ }^{\circ}$ that ${ }^{\circ}$ reaction ${ }^{\circ} 14^{\circ}$ occurs ${ }^{\circ}$ in the interface between the ESI spray needle and the first electrode leading to the evacuated region; the reactants being $\mathrm{NaCl}$ molecules and the charged protein (or peptide), both produced by the spray and both present in the gas-phase. We consider this process unlikely because most of the salt in this region will be present as positively charged clusters, which will be repelled by the charged protein (peptide). Some neutral salt clusters may be present also, but the presence of single $\mathrm{NaCl}$ ion pairs at sufficiently high gas densities appears unlikely. 


\section{Results with Sodium Acetate and Other Proteins: Cytochrome $c$ and Lysozyme}

Experimental results for cytochrome $c$ and lysozyme are given in Figures $10^{\circ}{ }^{\circ}$ and $^{\circ} 1$. These $^{\circ}$ spectra ${ }^{\circ}$ were obtained to examine whether eq 9 holds for these proteins. Initially, the conditions used for ubiquitin (large, $4 \mu \mathrm{m}$ diameter of the spray capillary tip, $375 \mathrm{~V} \mathrm{CAD}$, current $52 \mathrm{nA}, 5 \mathrm{mM} \mathrm{NaOAc}$ ) were tried. Unfortunately, this combination of conditions, required to obtain both sufficient adduct formation and adduct removal, could not readily be used with the larger lysozyme and cytochrome $c$. They led to very low ion intensities and, at times, unstable total protein ion current. With cytochrome $c$ a reproducible but relatively low intensity spectrum could be obtained using a $10 \mathrm{mM} \mathrm{NaAc}$ concentration, a $4 \mu \mathrm{m}$ tip, $400 \mathrm{~V} \mathrm{CAD}$, and a current of $65^{\circ} \mathrm{nA},{ }^{\circ}$ see $^{\circ}$ Figure ${ }^{\circ} 10$.

The spectrum of the major charge state $\mathrm{z}=7$ exhibits a fairly distinct break of the $n, 0$ series at $n=22$. That result and eq 9 lead to a prediction 15 acid sites at the surface ${ }^{\circ}$ of $^{\circ}$ cytochrome $^{\circ} \mathrm{C} .{ }^{\circ}$ Table $^{\circ} 1^{\circ}$ shows ${ }^{\circ}$ that ${ }^{\circ}$ the ${ }^{\circ}$ total number of acidic groups is 15 . However, one Glu90 and one heme acidic group are partly buried. The result from the spectrum indicates that these sites are sufficiently near the surface to be sodiated.

With lysozyme, a good spectrum could only be obtained using a $10 \mathrm{mM} \mathrm{NaAc}$ concentration, a $1 \mu \mathrm{m}$ tip, $450 \mathrm{~V}$ CAD, and a current of $23 \mathrm{nA}$. The low current indicates small initial droplets and relatively lower salt concentration in the final droplet containing the protein. The lysozyme spectrum of the major charge state $z$ $={ }^{\circ} 8,{ }^{\circ}$ Figure ${ }^{\circ} 11,{ }^{\circ}$ does $^{\circ}$ not $^{\circ}$ show $^{\circ} a^{\circ}{ }^{\circ}$ clear $^{\circ}$ break $^{\circ}$ in $^{\circ}$ the ${ }^{\circ} n, 0$ series. Instead, the series gradually fades away past $\mathrm{n}=$ 16. The number of acidic sites on the surface of lysozyme, ${ }^{\circ}$ Table $^{\circ} 1,{ }^{\circ}$ is $^{\circ} \mathrm{Nacid}^{\circ}={ }^{\circ}$, ${ }^{\circ}$ and ${ }^{\circ} \mathrm{eq}^{\circ} 9^{\circ}{ }^{\circ}$ would ${ }^{\circ}$ predict $\mathrm{n}_{\mathrm{MAX}}=8+9=17$. The lysozyme spectrum clearly indicates that the experimental conditions did not provide a high enough salt concentration in the final stage of the droplet. This is also evident from other features of the ${ }^{\circ}$ spectra. ${ }^{\circ}$ While ${ }^{\circ}$ for ${ }^{\circ}$ cytochrome ${ }^{\circ} c^{\circ}$, Figure $^{\circ} 10,{ }^{\circ}$ the highest intensity peak of the $n, 0$ series occurs at $n=16$, with lysozyme the maximum occurs at $n=3$.

We conclude that the experimental results available so far indicate that one can determine the number of acidic sites at the surface of (some) proteins. Additional experimental work would be required to establish whether the method is reliable and what experimental conditions and apparatus, electrospray or nanospray, would lead to the desired high salt conditions without loss of ion intensities.

All of the proteins used in this study have more basic than ${ }^{\circ}$ acidic ${ }^{\circ}$ sites, ${ }^{\circ}$ see Table $^{\circ}$. The ${ }^{\circ}$ question ${ }^{\circ}$ can be asked: Will the rule work also for proteins that have more acidic than basic sites? In the absence of a salt additive, the acidic sites that are in excess of the basic sites will be neutralized by their own $\mathrm{H}_{3} \mathrm{O}^{+}$counter ions before the solvent evaporates (see discussion in first paragraph of section, "Reaction Mechanisms leading to observed ions"). In the presence of a high concentration of salt $\mathrm{NaA}$, the much higher concentration of $\mathrm{Na}^{+}$will lead to preferential neutralization by $\mathrm{Na}^{+}$. Thus, the method is expected to work in all cases independent of the ratio of basic and acidic sites.

\section{Salt Bridges at the Surface of the Proteins}

The presence of salt bridges at the surface of the protein formed by ionized acidic and basic sites that happen to have ${ }^{\circ}$ just ${ }^{\circ}$ the ${ }^{\circ}$ right $^{\circ}$ distance, $^{\circ}$ is indicated ${ }^{\circ}$ in $^{\circ}$ Table $^{\circ} 1 .^{\circ}$ For example, six such pairs are indicated for ubiquitin. In the preceding discussion of the results for ubiquitin, cytochrome $c$, and lysozyme, we did not consider the presence of these bridges i.e., we assumed that they don't hinder $\mathrm{Na}^{+}$addition to the ionized acid groups involved in bridges. One must examine whether this approach is justified. In the final droplet where the concentration of the $\mathrm{Na}^{+}$ions becomes very high, particularly in the last stages of evaporation, the much more numerous $\mathrm{Na}^{+}$ions will likely also form ion pairs with the acidic groups that were part of a salt bridge, disrupting in this manner the salt bridge. A process of this type is indicated by the experimental results. These showed for ubiquitin that all $12^{\circ}$ acidic $^{\circ}$ sites ${ }^{\circ}$ formed ${ }^{\circ}$ adducts $^{\circ}$ with $^{\circ} \mathrm{Na}^{+},{ }^{\circ}$ see $^{\circ}$ discussion

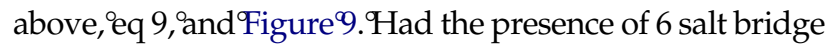
pairs blocked the sodiation, there would have been only 6 sodiated acidic sites. The same experimental result is also expected, had the positive ions of the salt additive been $\mathrm{NH}_{4}^{+}$ions. However, the neutralized acidic site would lose $\mathrm{NH}_{3}$ in the cleanup process and become a - $\mathrm{COOH}$ group, see eq 13b and the section, "Difference between proteins."

The experimental evidence that the presence of salt bridges at the surface of the protein does not prevent neutralization of the acidic site by the positive ion of the salt additive has a bearing for the conformation dependent neutralization ${ }^{\circ}$ theory ${ }^{\circ}(\mathrm{CDN})^{\circ}$ by $^{\circ} \mathrm{Grandori}^{\circ}$ and $^{\circ} \mathrm{CO}^{-}$ workers ${ }^{\circ}[27]^{\circ}\left(\right.$ see $^{\circ}$ also "The GDN model of Grandori." This model assumes that acidic sites that form salt bridges at the surface of the protein cannot be neutralized by positive ions present in the solution or as surface charges. The model also assumes that interactions of the ionized acidic site with neutral polar groups of the protein can prevent neutralization of the acidic site. The present results show that salt bridges do not prevent neutralization; therefore, one can also deduce that the much weaker stabilization of the ionized acidic site, when polar groups are involved, will also not prevent neutralization. The section on "The CDN model of Grandori" provides additional ${ }^{\circ}$ discussion ${ }^{\circ} f^{\circ} \mathrm{CDN}$ [27].

The ${ }^{\circ}$ fate ${ }^{\circ}$ of $^{\circ}$ the salt bridges in the absence of any salt additive is also of interest. When the solvent has evaporated and gas-phase conditions prevail, proton transfer from the ionized basic to the ionized acidic site will occur. The sites will be neutralized and will interact only via a hydrogen bond (see section, "The dissociation energy of ammonium acetate"). On the other hand, the remaining pairs of ionized acidic ${ }^{\circ}$ and basic $^{\circ}$ sites that are ${ }^{\circ}$ arther apart will remain ionized. 
The Dissociation Energy of $\mathrm{NH}_{4} \mathrm{OOCCH}_{3}$ in the Gas-Phase. Are Such Species Ion Pairs or Just H Bonded Neutrals?

To obtain insights in the energetic requirements and structures of $\mathrm{NH}_{4} \mathrm{OOCCH}_{3}$ salt bridges, calculations were performed with DFT, B3LYP/6-311 + + G(d,p). It was found that the lowest energy structure does not resemble the structure expected for the ion pair where two of the four $\mathrm{H}$ associated with $\mathrm{N}$ are each equidistant and aligned with an opposing carboxylic $\mathrm{O}$ atom. Instead, one of the $\mathrm{H}$ atoms is closer to a carboxylic $\mathrm{O}$ atom and the other to the $\mathrm{N}$ atom. Thus, the structure is close to the structure of neutral ammonia hydrogen bonded to acetic acid. The electronic bond energies, $\Delta \mathrm{E}$ $(\mathrm{kcal} / \mathrm{mol})$ for the reactions:

$$
\begin{aligned}
& \mathrm{CH}_{3} \mathrm{COOH}-\mathrm{NH}_{3}=\mathrm{NH}_{3}+\mathrm{CH}_{3} \mathrm{COOH} \quad \Delta \mathrm{E} \\
= & 11.2 \\
& \mathrm{CH}_{3} \mathrm{COOH}-\mathrm{NH}_{3}=\mathrm{CH}_{3} \mathrm{COO}^{-}+\mathrm{NH}_{4}^{+} \quad \Delta \mathrm{E} \\
= & 151.8
\end{aligned}
$$

were obtained. $\mathrm{CH}_{3} \mathrm{COOH}-\mathrm{NH}_{3}$ stands for the lowest energy structure. The very low energy for eq $15 \mathrm{a}$ is very close to that expected for an $\mathrm{H}$ bond that involves an essentially neutral $\mathrm{NH}_{3}$ and neutral $\mathrm{CH}_{3} \mathrm{COOH}$. Complexes with such low binding energies are certain to decompose easily in the cleanup stages of the interface even at very low CAD potentials.

Reaction 15a is a good model for the dissociation of the ammonium salts formed by the association of ionized acidic residues of the protein and $\mathrm{NH}_{4}^{+}$provided by the ammonium acetate present in the solution, see eqs $12 \mathrm{a}, 12 \mathrm{~b}$. It can also be used as model for dissociation of complexes formed between the acetate anion and ionized basic residues of the protein, see eqs 12a, $12 \mathrm{~b}$. However, in this case an upward correction of the binding energies is required. The gas-phase basicity of basic residues is considerably higher than that of $\mathrm{NH}_{3}$. Thus, GB $\left(\mathrm{NH}_{3}\right)^{\circ}={ }^{\circ} 197.5^{\circ} \mathrm{kcal} / \mathrm{mol}^{\circ}[19]^{\circ}{ }^{\text {while }}{ }^{\circ}$ that ${ }^{\circ}$ of n-butyl amine that model lysine, $\mathrm{GB}\left(\mathrm{n}-\mathrm{C}_{4} \mathrm{H}_{9} \mathrm{NH}_{2}\right)=212$ $\mathrm{kcal} / \mathrm{mol}^{\circ}[19] .{ }^{\circ}$ Stronger ${ }^{\circ}$ gas-phase $^{\circ}$ bases $^{\circ}$ will $^{\circ}$ stabilize the ionic form of the complex between the ionized basic residue and the acetate anion, $\mathrm{Ac}^{-}$. The binding energy for the dissociation is expected to increase by a few $\mathrm{kcal} / \mathrm{mol}$ over $11.2 \mathrm{kcal} / \mathrm{mol}$. These somewhat higher bond energies will not prevent a facile dissociation of the complex in the cleanup stages.

\section{The CDN Model of Grandori and Coworkers for Formation of Multiply Charged Proteins}

The experimental observations in the present work were interpreted on the basis of the charge residue model $^{\circ} \mathrm{CRM}^{\circ}$ for ${ }^{\circ}$ folded ${ }^{\circ}$ proteins $[9],{ }^{\circ}$ see $^{\circ}$ the Introduction. ${ }^{\circ}$ Grandori $^{\circ}$ and $^{\circ}$ coworkers ${ }^{\circ}[27]^{\circ}$ have ${ }^{\circ}$ recently proposed a different model whose basic tenets were first $^{\circ}$ stated $^{\circ}$ by $^{\circ} \mathrm{Katta}^{\circ}$ and $^{\circ} \mathrm{Chait}^{\circ}[28]^{\circ}$ “ "The ${ }^{\circ}$ multiply charged ions observed in the positive ion spectra are produced by proton attachment to basic and deprotonated ${ }^{\circ}$ acidic ${ }^{\circ}$ sites $^{\circ}{ }^{\circ}{ }^{\circ}$ the ${ }^{\circ}$ protein ${ }^{\circ}$ and $^{\circ}{ }^{\circ}$ reflect ${ }^{\circ}$ to $^{\circ}$ some extent the degree of protonation in solution." Grandori $^{\circ}$ and $^{\circ}$ coworkers $^{\circ}\left[27 \mathrm{a}^{\circ} \mathrm{provide}^{\circ}\right.$ an $^{\circ}$ important $^{\circ}$ extension ${ }^{\circ}$ of $^{\circ}$ the ${ }^{\circ}$ tenets ${ }^{\circ}\left[28\right.$. $^{\circ}$ The ${ }^{\circ}$ basic ${ }^{\circ}$ idea $^{\circ}{ }^{\circ}{ }^{\circ}$ simple. ${ }^{\circ}$ In folded proteins a significant percentage of ionized basic and acidic groups can be buried inside the protein, e.g., as pairs forming a salt bridge. Such interactions are used in nature to stabilize the tertiary structure of folded proteins. Each buried ion pair will lead to loss of one charge relative to that when the groups ${ }^{\circ}$ were $^{\circ}$ not $^{\circ}$ buried..$^{\circ} \mathrm{It}^{\circ}{ }^{\circ} \mathrm{s}^{\circ}$ also ${ }^{\circ}$ assumed ${ }^{\circ}[27]^{\circ}$ that single ionized acidic sites can be protected from neutralization even when on the surface of the protein. This would be the case when the conformation is favorable, so that the acidic site can be stabilized by interacting with a neutral polar group of the protein. With these assumptions, it follows that the higher charge observed for unfolded relative to folded proteins is due to the absence of the protecting, folded protein conformation. Thus, an attractive explanation is $^{\circ}$ provided $^{\circ}$ for $^{\circ}$ the ${ }^{\circ}$ experimentally ${ }^{\circ}$ observed ${ }^{\circ}$ higher charges for unfolded proteins. Predictions of the charge ${ }^{\circ}$ states $^{\circ}$ of $^{\circ}$ several $^{\circ}$ proteins ${ }^{\circ}$ were $^{\circ}$ given $^{\circ}\left(\right.$ Table $^{\circ} 1$, [27a]). ${ }^{\circ}$ These ${ }^{\circ}$ were $^{\circ}$ based $^{\circ}$ on $^{\circ}$ the ${ }^{\circ}$ limiting $^{\circ}$ case $^{\circ}$ where all possible ion pairs are not accessible to charging. The $\mathrm{Z}(\mathrm{CDN})$ predicted in that case corresponds to the difference ${ }^{\circ}$ between ${ }^{\circ}$ the $^{\circ}$ basic $^{\circ}$ and $^{\circ}$ acidic $^{\circ}$ sites $^{\circ}[27 \mathrm{a}]$. This limiting model was assumed to be the prevailing condition for folded proteins.

In an attempt to further test the limiting model, Nesatyy ${ }^{\circ}$ and ${ }^{\text {SSuter }}$ [29] ${ }^{\circ}$ examined ${ }^{\circ}{ }^{\circ}$ much larger number of proteins and found that the agreement with the observed charge state was poor. They considered this as a proof against the CDN model especially since they found good agreement of the observed charges with the $\mathrm{CRM}^{\circ}$ model ${ }^{\circ}[9]$.

However, ${ }^{\circ}$ neither ${ }^{\circ}$ Grandori $\left.^{\circ}\left[27 a,{ }^{\circ} 27 b\right)\right]^{\circ}$ nor ${ }^{\circ}$ Nesatyy and $^{\circ}$ Suter ${ }^{\circ}[29]^{\circ}$ considered $^{\circ}$ using $^{\circ} X-$ ray $^{\circ}{ }^{\circ}{ }^{\circ} \mathrm{NMR}^{\circ}$ information to determine the number of salt bridges and their location in the various proteins. Such information is essential for estimating the number of ion pairs in solution because the buried salt bridges provide the most convincing case for acidic sites that are protected from neutralization.

Table $^{\circ} 1^{\circ}$ provides $^{\circ}$ such $^{\circ}$ information ${ }^{\circ}$ for ${ }^{\circ}$ ubiquitin, cytochrome $c$, and lysozyme. Practically all acidic sites are at the surface of these proteins. The number of acidic sites at the surface of the proteins that can form salt ${ }^{\circ}$ bridges $9 s^{\circ}$ also given in $^{\circ} \mathrm{Table}^{\circ} 1 .{ }^{\circ} \mathrm{A}^{\circ} \mathrm{comparison}^{\circ}$ of the various models for cytochrome $c$, lysozyme, and ubiquitin ${ }^{\circ}$ s $^{\circ}$ presented ${ }^{\circ}{ }^{\circ}{ }^{\circ}$ Table $^{\circ} 2 .{ }^{\circ} \mathrm{Z}(\mathrm{CDN})^{\circ}$ given ${ }^{\circ}$ in ${ }^{\circ}$ Table 2 is $^{\circ}$ the $^{\circ}$ "limiting ${ }^{\circ}$ case $^{\prime \prime}$ charge $^{\circ}[27 \mathrm{a}]^{\circ}{ }^{\circ} \mathrm{It}^{\circ}$ leads $^{\circ}$ to $^{\circ}$ good agreement with the observed charges $\mathrm{Z}$ (obs) for lysozyme and cytochrome $c$, but a much lower predicted $\mathrm{Z}(\mathrm{CDN})=1$ for ubiquitin, whose $\mathrm{Z}(\mathrm{obs})=6$. Correction by using the actual number of salt bridges indicated by 
Table 2. Positive ${ }^{\circ} \mathrm{Charge}^{\circ}$ predicted ${ }^{\circ} \mathrm{by}^{\circ} \mathrm{CDN}^{\circ} \mathrm{Model}^{\circ}[27],{ }^{\circ} \mathrm{CRM}$ and experimentally observed ${ }^{\mathrm{a}}$

\begin{tabular}{lccc}
\hline & UBI & LYS & CYC \\
\hline \hline Number of basic sites & 13 & 19 & $24^{\mathrm{b}}$ \\
& $\{13\}^{\mathrm{c}}$ & $\{20\}^{\mathrm{c}}$ & $\{26\}^{\mathrm{c}}$ \\
Number of acidic sites & 12 & 10 & 15 \\
& $\{12\}^{\mathrm{c}}$ & $\{10\}^{\mathrm{c}}$ & $\{13\}^{\mathrm{d}}$ \\
Salt Bridges & 6 & 3 & $6^{\mathrm{e}}$ \\
& & & \\
Predicted Charge & 1 & 9 & 9 \\
Z(CDN) & & $\{10\}^{\mathrm{c}}$ & $\{13\}^{\mathrm{c}}$ \\
Salt Bridge Corrected & $\{1\}^{\mathrm{c}}$ & 16 & 19 \\
Z(CDN) & 7 & 9 & 9 \\
Z(CRM) & & & \\
Experimentally Observed Charge & 6 & $8-9$ & $7-9$ \\
Z(obs) & 6 & & \\
\hline
\end{tabular}

${ }^{a}$ Data for number of acidic, basic and salt bridges from Table 1.

${ }^{b}$ Cytochrome $c$ is $\mathrm{N}$-acetylated, resulting in 24 basic groups. An additional charge for both the heme group and the $\mathrm{N}$-terminal is counted in ref. [27a].

'In brackets \{\} data from table 1, ref. [27a].

${ }^{\mathrm{d}}$ Ref. [27a] does not include the contribution of two acidic residues on the Heme group.

eAverage of data from NMR and X-ray structures.

${ }^{f}$ Charges evaluated for limiting case without consideration of location of acid base ion pairs or buried His residues using CDN model. Z(CDN) $=$ \# basic sites - \# acidic sites.

${ }^{\text {g}}$ Charges evaluated using CDN model, using NMR, X-ray structures to determine the number of salt bridges. $Z(C D N)=\#$ basic sites $-\#$ salt bridges.

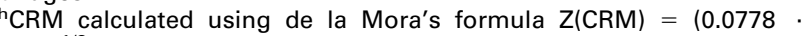
$\left.(\mathrm{MW})^{1 / 2}\right)$.

'Data based on this publication and reference [27a].

the NMR and X-ray structures leads to salt bridge corrected $\mathrm{Z}(\mathrm{CDN})$ for cytochrome $c$ and lysozyme that are much higher than $\mathrm{Z}(\mathrm{obs})$, but correct for the predicted charge for ubiquitin.

The experimentally observed sodium adducts to ubiquitin (see section, "Salt bridges at the surface of the proteins") indicated that all the acidic sites are accessible to neutralization. This means that the acidic sites of the six ion pairs, which according to the structural information are located near the surface of ubiquitin, were also neutralized. Therefore, the predicted agreement $^{\circ}\left(\text { see }^{\circ} \text { Table }^{\circ} 2\right)^{\circ}$ of $^{\circ}$ the ${ }^{\circ}$ salt ${ }^{\circ}$ bridge ${ }^{\circ}$ corrected $^{\circ} \mathrm{Z}(\mathrm{CDN})$ with $\mathrm{Z}$ (obs) is questionable. Acidic sites in salt bridges located at the surface may be accessible to neutralization even at lower salt concentrations than those used in the present experiments. If acidic sites or salt bridges at the surface can be neutralized, the neutralization of acidic sites at the surface that are protected by the weaker interactions with polar groups is even more likely.

Results including ubiquitin, RNase, and five mutants of $^{\circ}$ RNase $^{\circ}$ presented $^{\circ}$ in $^{\circ}[27 \mathrm{~b}]^{\circ}$ led $^{\circ}$ to $^{\circ} \mathrm{a}^{\circ}$ revision $^{\circ}$ of ${ }^{\circ}$ the model ${ }^{\circ}[27 \mathrm{a}] .{ }^{\circ}$ RNase ${ }^{\circ}{ }^{\circ}{ }^{\circ} \mathrm{basic}^{\circ}{ }^{\circ} \mathrm{and}^{\circ} 13^{\circ}$ acidic $^{\circ}$ sites ${ }^{\circ}$ while in the mutants the acidic groups are stepwise replaced by basic groups, such that the last mutant had 13 basic and 8 acidic sites. The observed charge states for all of these were the same, $\mathrm{Z}$ (obs) $=8$ or 9 (it should be noted that the predicted $Z(C R M)=8$ or 9$)$. The failure of
$\mathrm{Z}(\mathrm{CDN})^{\circ}$ was $^{\circ}$ explained $^{\circ}[27 \mathrm{~b}]^{\circ}$ on $^{\circ}$ the $^{\circ}$ basis $^{\circ}$ of $^{\circ}$ an $^{\circ}$ additional hypothesis that would be valid for proteins such as ubiquitin and RNase.

We ${ }^{\circ}$ consider the ${ }^{\circ} \mathrm{CDN}$ model [27] to ge $^{\text {qunsatisfactory }}$ in its present state because it does not take into account information from both the solid-state (X-ray) and solution (NMR) structures of the proteins. Such information sets parameters from which one should approach reasoning for the CDN model.

Grandoriand ${ }^{\circ}$ coworkers $[27]^{\circ}$ did $^{\circ}$ not ${ }^{\circ}$ mention ${ }^{\circ}$ explicitly whether in their model the protein enters the gas-phase via CRM or via the ion evaporation model $\operatorname{IEM}^{\circ}\left[23,{ }^{\circ} 24\right] .{ }^{\circ}$ First $^{\circ}$ we $^{\circ}$ consider $^{\circ} \mathrm{CRM}^{\circ}{ }^{\circ}$ The $^{\circ}$ discussion ${ }^{\circ}$ in the present work, see second paragraph after eqs 3, 4, did point out that with CRM, the charge state of the protein in the solution of the final droplet cannot make a contribution to the observed charge in the gas-phase. The reason for this was that counter ions due to an excess of acidic or basic ionized sites lead to an overall charge neutrality of the solution inside the droplet. Because the droplets are very small, some statistical charging due fluctuation in the number of counter ions will ${ }^{\circ}$ be $^{\circ}$ present, $^{\circ}$ see $^{\circ}[30]^{\circ}$ and $^{\circ}$ references $^{\circ}$ therein. ${ }^{\circ} \mathrm{How}-$ ever this "statistical charging" is very small, leading to differences of only a few charge units. It follows that charging of the protein produced by CRM will be due only to the excess ions at the surface of the droplet.

Because the Grandori charging model includes the charge of the protein in the solution, it cannot proceed by CRM. It is possible only with the IEM. With IEM the ions can leave the droplet retaining the charge that they had in the solution without taking counter ions with them, yet also gaining charge from surface ions. The ion evaporating protein does not have to take all the charge present on the surface of the droplet. In fact, it is unlikely that it will be able to do so since the surface of the droplet will be much larger than the size of the protein. This means that even if there are accessible acidic sites at the surface of the protein, these need not be all neutralized as the protein escapes from the droplet. For this reason, quantitative predictions of the charge of the protein in the gas-phase cannot be made with the CDN model. Only an upper limit can be set, see $^{\circ}$ Table $^{\circ} 2,{ }^{\circ}$ predicted ${ }^{\circ}$ charges,,$^{\circ}$ salt ${ }^{\circ}$ bridge ${ }^{\circ}$ corrected $\mathrm{Z}(\mathrm{CDN})$.

It should be noted that the reactions (eq 3-8) proposed in the preceding discussion are compatible with IEM, for an example see discussion of results for peptides below eq 9 .

The question must be asked: Can macro ions such as the folded proteins be produced by IEM? While both experimental and theoretical treatments support the validity ${ }^{\circ}$ of $^{\circ} \mathrm{IEM}^{\circ}$ for $^{\circ}$ small $^{\circ}{ }^{\circ}$ ions $^{\circ}[3],{ }^{\circ}$ no $^{\circ}$ theoretical ${ }^{\circ}$ treatment has been attempted for macro-ions. The escape of macro-ions from the small droplets is considered very unlikely, ${ }^{\circ}$ see $^{\circ}$ page $^{\circ} 4^{\circ}$ in $^{\circ}[9] . .^{\circ}$ Furthermore, ${ }^{\circ}$ the ${ }^{\circ}$ charge states of the close to spherical Starburst dendrimer macro-ions with molecular weight up to 1 mega Dalton, observed ${ }^{\circ}$ experimentally, ${ }^{\circ}[31]^{\circ}$ were $^{\circ}$ found ${ }^{\circ}$ to ${ }^{\circ} e^{\circ}$ in ${ }^{\circ}$ very 


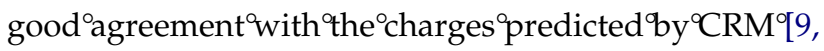
31]..$^{\circ}$ The ${ }^{\circ}$ dendrimers ${ }^{\circ}$ have $^{\circ}$ onl $y^{\circ}$ basic $^{\circ}$ groups ${ }^{\circ}$ (primary and tertiary amines) and therefore conformation dependent acid neutralization effects proposed for proteins [27] ${ }^{\circ}$ cannot $^{\circ}$ occur. Therefore, ${ }^{\circ}$ one ${ }^{\circ}$ can $^{\circ}$ ask: If $^{\circ}$ dendrimers are produced by CRM, why should folded proteins which are of similar size and shape not also be produced by CRM?

However, there appears to be one problem with $\mathrm{CRM}^{\circ}[9] .{ }^{\circ}$ The $^{\circ}$ charge $^{\circ}$ states $^{\circ}$ of ${ }^{\circ}$ presumably ${ }^{\circ}$ folded ${ }^{\circ}$ proteins in 1-propanol and 1,2 -propylene glycol determined ${ }^{\circ}$ by $^{\circ}$ experiment ${ }^{\circ}[32]^{\circ}$ were ${ }^{\circ}$ found ${ }^{\circ}$ not ${ }^{\circ}$ to ${ }^{\circ}$ obey ${ }^{\circ}$ the Rayleigh equation. These solvents have much lower surface tension than water and should have led to charge states that were lower than those observed with water. Contrary to that prediction, the charge states were close to those expected for water as solvent. Confirmation of this problem by measurements that include other nonaqueous solvents by other laboratories is desirable.

The $^{\circ}$ authors ${ }^{\circ}$ consider $^{\circ}$ that ${ }^{\circ}$ the ${ }^{\circ} \mathrm{CRM}^{\circ}[9]^{\circ}$ for ${ }^{\circ}$ folded proteins ${ }^{\circ}$ is $^{\circ}$ much $^{\circ}$ more $^{\circ} l i k e l y^{\circ}$ than ${ }^{\circ}$ the ${ }^{\circ}$ model ${ }^{\circ}[27]^{\circ}$ that requires the IEM. CRM provides very good quantitative predictions ${ }^{\circ}{ }^{\circ}$ or ${ }^{\circ}$ the ${ }^{\circ}$ charge $^{\circ}$ states $^{\circ}\left[9,{ }^{\circ} 10 a,{ }^{\circ} 10 c,{ }^{\circ} 29\right],{ }^{\circ}$ while the ${ }^{\circ}$ model $^{\circ}[27]^{\circ}$ provides $^{\circ}$ qualitative $^{\circ}$ predictions ${ }^{\circ}$ for ${ }^{\circ}$ the charge that often must be adjusted for special cases.

It must be recognized that the overall process that leads from proteins in solution to the protein ions observed in the mass spectrum is exceedingly complex. Alternatives considered above are based on indirect evidence. Therefore neither "proof" can be considered as definitive. Possibly, folded proteins can be produced by a modified form of IEM that blurs the distinction between IEM and CRM. Models where the protein distorts the droplet surface, so that fission of the droplet at the point of disruption occurs, have been considered before ${ }^{\circ}\left[10 c^{,}, 33\right] .{ }^{\circ}$ In $^{\circ}$ that ${ }^{\circ}$ case $^{\circ}$ an $^{\circ}$ improved $^{\circ} \mathrm{CDN}^{\circ}$ model that also considers structural information of folded proteins (X-ray, NMR) and considers the relaxed conditions ${ }^{\circ}$ by ${ }^{\circ}$ the IEM-CRM ${ }^{\circ}\left[10 c^{\circ}, 33\right]^{\circ}$ might $^{\circ}$ turn $^{\circ}$ out ${ }^{\circ}$ to ${ }^{\circ}$ be the valid model.

\section{Conclusions}

1. When proteins are sprayed from aqueous solution without any salt additives, the charged protein observed in the gas-phase is expected to have many ionized acidic and ionized basic groups due to basic and acidic residues and terminal amino and carboxylic groups that happen to be at the surface of the protein. The presence of such ionized groups is predicted by this work and could be tested for by methods such as those used by Stephensen and McLuckey $[17,918]$. Very $^{\circ}{ }^{\circ}$ lean mass ${ }^{\circ}$ spectra, ${ }^{\circ}$ charged by protons, are expected under these conditions.

2. The addition of the buffer salt $\mathrm{NH}_{4}$ Ac to the solution in $\mathrm{mM}$ concentrations will lead to the neutralization of the formerly ionized acidic and basic groups. This neutralization occurs in the final stages of the charged droplet containing the protein, by formation of ion pairs between the $\mathrm{NH}_{4}^{+}$ions and the ionized acidic groups and $\mathrm{Ac}^{-}$ions and the ionized basic groups of the proteins. The ion pairing is driven by the very high salt concentration which is due to extensive solvent evaporation from the droplets. Very clean spectra are observed because the $\mathrm{NH}_{4}^{+}$adducts to the ionized acidic groups and the $\mathrm{Ac}^{-}$adducts to the ionized basic groups fall off readily as $\mathrm{NH}_{3}$ and $\mathrm{AcH}$ in the clean up stages of the mass spectrometer.

3. When a NaA salt where $\mathrm{A}^{-}=\mathrm{I}^{-}, \mathrm{Cl}^{-}, \mathrm{Ac}^{-}$is used instead of $\mathrm{NH}_{4} \mathrm{Ac}$, the $\mathrm{Na}^{+}$that neutralizes the ionized acidic groups remain on the acidic groups and are detected in the spectrum while $\mathrm{AH}$ dissociates from the basic groups in the clean up stage. Experiments with increasing CAD potential show that the dissociation of $\mathrm{AH}$ becomes more facile in the order: $\mathrm{HI}<\mathrm{HCl}<\mathrm{HAc}$. This is exactly the order expected for the proposed gas-phase reactions. The number of $\mathrm{Na}$ adducts observed after the dissocia-

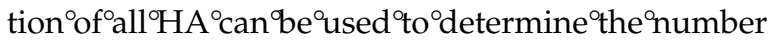
of acidic groups at the surface of the protein.

4. The proposed reactions not only conform with the observed mass spectra but are also expected to occur on the basis of the charged residue model, for the generation by electrospray or nanospray of charged folded ${ }^{\circ}$ proteins $^{\circ}$ in $^{\circ}$ the ${ }^{\circ}$ gas-phase ${ }^{\circ}$ by $^{\circ} \mathrm{de}^{\circ} \mathrm{la} \mathrm{a}^{\circ} \mathrm{Mora}^{\circ}[9]$ and expanded in previous work from this laboratory. The mechanism by Grandori and coworkers [27] ${ }^{\circ}$ is $^{\circ}$ compatible $^{\circ}$ with $^{\circ}$ most $^{\circ}$ of ${ }^{\circ}$ the ${ }^{\circ}$ present $^{\circ}$ experimental observations, except for the very large number of $\mathrm{NaA}$ adducts indicated by the mass spectra, see $^{\circ}$ Figure $^{\circ} 6 .{ }^{\circ}$ Such $^{\circ} a^{\circ}$ large ${ }^{\circ}$ number ${ }^{\circ}$ is ${ }^{\circ}$ not ${ }^{\circ}$ expected with ${ }^{\circ} \mathrm{IEM}^{\circ}$ but $^{\circ}$ is $^{\circ}$ expected $^{\circ}$ with $^{\circ} \mathrm{CRM}^{\circ}[10 \mathrm{c}]$.

\section{Acknowledgments}

The ab initio calculations for $\mathrm{NH}_{4} \mathrm{Ac}$ were performed by Dr. Michael Peschke. This work was supported by a grant from the Natural Sciences and Engineering Research Council (NSERC) of Canada.

\section{References}

1. (a) Neubauer, G.; Anderegg, R. Identifying Charge States of Peptides in Ligand Chromatography/Electrospray Ionization Mass Spectrometry. J. Anal. Chem. 1994, 66, 1056-1061; (b) Rodriquez, C. F.; Fournier, R.; Chu, I. K.; Hopkinson, A. C.; Siu, M. W. A Possible Origin of $[\mathrm{M}-\mathrm{nH}+\mathrm{mX}]^{(\mathrm{m}-\mathrm{n})+}$ Ions $(X$ $=$ Alkali Metal Ions) in Electrospray of Peptides. Int. J. Mass Spectrom. 1999, 192, 303-317; (c) Rodriquez, C. F.; Guo, X.; Shoeib, T.; Hopkinson, A. C.; Siu, M. W. Formation of [M $\mathrm{nH}+\mathrm{mNa}]^{(\mathrm{m}-\mathrm{n})+}$ and $[\mathrm{M}-\mathrm{nH}+\mathrm{mK}]^{(\mathrm{m}-\mathrm{n})+}$ Ions in Electrospray Mass Spectrometry of Peptides and Proteins. J. Am. Soc. Mass Spectrom. 2000, 11, 967-975; (d) Ogorzalek, R. R.; Dales, P. C. Andrews, N.; Surfactant Effects on Protein Structure Examined by Electrospray Ionization Mass Spectrometry. Protein Sci. 1994, 3, 1975-1983; (e) Rundlett, K. L.; Armstrong, D. W. Mechanism of Signal Suppression by 
Anionic Surfactants in Capillary Electrophoresis-Electrospray Ionization Mass Spectrometry. Anal. Chem. 1996, 68, 3493-3497; Pan, P.; McLuckey, S. A. The Effect of Small Cations on the Positive Electrospray Responses of Proteins at Low pH. Anal. Chem. 2003, 75, 5468-5474; (f) Holcapek, M.; Volna, K.; Jandera, P.; Kolarova, L.; Lemr, K.; Exner, M.; Cirkva, A. Effects of Ion-Pairing Reagents on the Electrospray Signal Suppression of Sulphonated Dyes and Intermediates. J. Mass Spectrom. 2004, 39, 43-50; (g) Benkestock, K.; Sundquist, G.; Edlund, P.; Roeraade, J. Influence of Droplet Size, Capillary-Cone Distance, and Selected Instrumental Parameters for the Analysis of Noncovalent ProteinLigand Complexes by Nano-Electrospray Ionization Mass Spectrometry. J. Mass Spectrom. 2004, 39, 1059-1067; (h) Iavarone, A. T.; Udekwu, O. A.; Williams, E. R. Buffer Loading for Counteracting Metal Salt-Induced Signal Suppression in Electrospray Ionization. Anal. Chem. 2004, 76, 3944-3950.

2. (a) Kebarle, P.; Tang, L. From Ions in Solution to Ions in the Gas Phase-The Mechanism of Electrospray Mass Spectrometry. Anal. Chem. 1993, 65, A972-A986; (b) Tang, L.; Kebarle, P. Dependence of the Ion Intensity in Electrospray Mass Spectrometry on the Concentration of the Analytes in the Electrosprayed Solution. Anal. Chem. 1993, 65, 3654-3668.

3. Kebarle, P.; Ho. Y. On the Mechanism of Electrospray Mass Spectrometry. In Electrospray Mass Spectrometry; Cole, R. B., Ed.; Wiley Interscience Publications, John Wiley and Sons: New York, NY 1997; p 1.

4. Li, J.; Taraszka, J. A.; Counterman, A. E.; Clemmer, D. E. Influence of Solvent Composition and Capillary Temperature on the Conformations of Electrosprayed Ions: Unfolding of Compact Ubiquitin Conformers from Pseudonative and Denatured Solutions. Int. J. Mass Spectrom. 1999, 185/186/187, 37-47.

5. Blades, A. T.; Ikonomou, M. G.; Kebarle, P. Mechanism of Electrospray Mass Spectrometry. Electrospray as an Electrolysis Cell. Anal. Chem. 1991, 64, 2109-2114.

6. Van Berkel, G. E.; Assano, K. G.; Schnier, P. D. Electrochemical Processes in a Wire-in-a-Capillary Bulk Loaded Nano-Electrospray Emitter. J. Am. Soc. Mass Spectrom. 2001, 12, 853-862.

7. Peschke, M.; Verkerk, U.; Kebarle, P. Features of the ESI Mechanism that Affect the Observation of Multiply Charged Noncovalent Protein Complexes and the Determination of the Association Constant by the Titration Method. J. Am. Soc. Mass Spectrom. 2004, 15, 1424-1434.

8. (a) Smith, J. N.; Flagan, R. C.; Beauchamp, J. L. Droplet Evaporation and Discharge Dynamics in Electrospray Ionization. J. Phys. Chem. A 2002, 106, 9957-9967; (b) Grimm, L. R.; Beauchamp, J. L. Evaporation and Discharge Dynamics of Highly Charged Droplets of Heptane, Octane, and $p$-Xylene Generated by Electrospray Ionization. Anal. Chem. 2002, 74, 6291-6297.

9. de la Mora, J. F. Electrospray Ionization of Large Multiply Charged Species Proceeds via Dole's Charged Residue Mechanism. Anal. Chim. Acta 2000, 408, 93-104.

10. (a) Felitsyn, N.; Peschke, M.; Kebarle, P. Origin and Number of Charges Observed on Multiply Protonated Native Proteins Produced by ESI. Int. J. Mass Spectrom. 2002, 219, 39-62; (b) Peschke, M.; Blades, A. T.; Kebarle, P. Charged States of Proteins. Reactions of Doubly Protonated Alkyl Diamines with $\mathrm{NH}_{3}$ : Solvation or Deprotonation. Extension of Two Proton Cases to Multiply Protonated Globular Proteins Observed in the Gas Phase. J. Am. Chem. Soc. 2002, 124, 1151911530; (c) Verkerk, U.; Peschke, M.; Kebarle, P. Effect of Buffer Cations and $\mathrm{H}_{3} \mathrm{O}^{+}$on the Charge States of Native Proteins. Significance to the Determination of Stability Constants of Protein Complexes. J. Mass Spectrom. 2003, 38, 618-631.
11. (a) Schmidt, A.; Karas, M; Dulks. T. Effect of Different Solution Flow Rates on Analyte Ion Signals in Nano-ESI MS, or When Does ESI Turn into Nano-ESI? J. Am. Soc. Mass Spectrom. 2003, 14, 492-500; (b) Anacleto, J. F.; Pleasance, S.; Boyd, R. K. Calibration of Mass Spectra Using Cluster Ions. Org. Mass Spectrom. 1992, 27, 660-666.

12. Myung, S.; Badman, E. R.; Lee, Y. J.; Clemmer, D. E. Structural Transitions of Electrosprayed Ubiquitin Ions Stored in an Ion Trap over $10 \mathrm{~ms}$ to 30 s. J. Phys. Chem. A 2002, 106, 9976-9982.

13. Blades, A. T.; Peschke, M.; Verkerk, U. H.; Kebarle, P. Hydration Energies in the Gas Phase of Select $(\mathrm{MX})_{\mathrm{m}} \mathrm{M}^{+}$Ions where $\mathrm{M}^{+}=\mathrm{Na}^{+}, \mathrm{K}^{+}, \mathrm{R}^{+}, \mathrm{Cs}^{+}, \mathrm{NH}_{3}^{+}$, and $\mathrm{X}^{-}=\mathrm{F}^{-}, \mathrm{Cl}^{-}, \mathrm{Br}^{-}, \mathrm{I}^{-}$, $\mathrm{NO}_{2}^{-}, \mathrm{NO}_{3}^{-}$. Observed Magic Numbers of $(\mathrm{MX})_{\mathrm{m}} \mathrm{M}^{+}$Ions and their Possible Significance. J. Am. Chem. Soc. 2004, 126, 19952003.

14. (a) Barlow, S. E.; van Doren, J. M.; Depuy, C. H.; Bierbaum, V. M.; Dotan, I.; Ferguson, E.; Adams, N. G.; Smith, D.; Rowe, R. R.; Marquette, J. B.; Dupereyat, G.; Durup-Ferguson, M. Studies of Reactions of $\mathrm{O}_{2}^{+}$with Deuterated Methanes. J. Chem. Phys. 1988, 85, 3851-3859; (b) Bure, C.; Lange, L. Comparison of Dissociation of Ions in an Electrospray Source, or a Collision Cell in Tandem Mass Spectrometry. Curr. Org. Chem. 2003, 7, 1613-1624.

15. Klibanov, A. M. Improving Enzymes by Using them In Organic Solvents. Nature 2001, 409, 241-246.

16. Sundd, M.; Iverson, N.; Ibarra-Molero, B.; Sanchez-Ruiz, J. M.; Robertson, A. D. Electrostatic Interactions in Ubiquitin: Stabilization of Carboxylates by Lysine Amino Groups. Biochemistry 2002, 41, 7586-7596.

17. Stephenson, J. L.; McLuckey, S. A. Gaseous Protein Cations are Amphotheric. J. Am. Chem. Soc. 1997, 119, 1688-1696.

18. Stephenson, J. L.; McLuckey, S. A. Counting Basic Sites in Oligopeptides via Gas Phase Ion Chemistry. Anal. Chem. 1997, 69, 281-286.

19. NIST Standard Reference Database; http://webbook.nist.gov. chemistry.

20. Klassen, J. S.; Anderson, S. G.; Blades, A. T.; Kebarle, P. Reaction Enthalpies for $\mathrm{M}^{+} \mathrm{L}=\mathrm{M}^{+}+\mathrm{L}$ where $\mathrm{M}^{+}\left(\mathrm{Na}^{+}\right.$, $\mathrm{K}^{+}$) and $\mathrm{L}$ (acetamide, N-methyl-acetamide, glycine, and glycylglycine) from the Determination of the Collision Induced Dissociation Thresholds. J. Phys. Chem. 1996, 100, 14218-14227.

21. Cerda, B. A.; Hoyan, S.; Ohanessian, G.; Wesdemiotis, C. $\mathrm{Na}^{+}$ Binding to Cyclic and Linear Dipeptides. Bond Energies, Entropies of $\mathrm{Na}^{+}$Complexation, and Attachment Sites from Dissociation of $\mathrm{Na}^{+}$-Bond Heterodimers and $\mathrm{Ab}$ Initio Calculations. J. Am. Chem. Soc. 1998, 120, 2437-2448.

22. Timoleer, O.; Zhu, M. M.; Gross, M. L. Information for Proteomics: ESI-MS Titration by Sodium Ions Gives Number of Carboxylate Groups in Peptides. Int. J. Mass Spectrom. 2004, 231, 113-117.

23. (a) Thomson, B. A.; Iribarne, J. V. Field Induced Ion Evaporation from Liquid Surfaces at Atmospheric Pressures. J. Chem. Phys. 19769, 71, 4451-4462; (b) Iribarne, J. V.; Thomson, B. A. On the Evaporation of Small Ions from Charged Droplets. J. Chem. Phys. 1976, 64, 2287-2294.

24. Ganero Castano, M.; Fernandez de la Mora, J. Mechanism of Electrospray Ionization of Singly and Multiply Charged Salt Clusters. Anal. Chim. Acta 2000, 406, 67-91.

25. (a) Cumming, J. B.; Kebarle, P. Summary of Gas Phase Acidities Measurements Involving Acids AH. Entropy Changes in Proton Transfer Reactions Involving Negative Ions. Bond Dissociation Energies $\mathrm{D}(\mathrm{A}-\mathrm{H})$ and Electron Affinities EA(A). Can. J. Chem. 1978, 56, 1-9; (b) Hornstrop, D.; Gustavson, M. Determination of the Electron Affinity of Iodine. J. Phys. B 1992, 25, 1773-1777. 
26. Felitsyn, N.; Kitova, E. N.; Klassen, J. S. Thermal Decomposition of a Gaseous Multiprotein Complex Studied by Blackbody Infrared Radiative Dissociation. Investigating the Origin of the Asymmetric Dissociation Behavior. Anal. Chem. 2001, 73, 4647-4661.

27. (a) Grandori, R. Origin of the Conformation Dependence of Protein Charge State Distributions of Electrospray Mass Spectrometry. J. Mass Spectrom. 2003, 38, 11-15; (b) Samalikova, M.; Grandori, R. Role of Opposite Charges in Protein Electrospray Ionization Mass Spectrometry. J. Mass Spectrom. 2003, 38, 941-947.

28. Katta, V.; Chait, B. T. Observations of the Heme-Globin Complex in Native Myoglobin by Electrospray Mass Spectrometry. J. Am. Chem. Soc. 1991, 113, 8534-8535.

29. Nesatyy, V. J.; Suter, J. F. On the Conformation Dependent Neutralization Theory and Charging of Individual Proteins and Their Noncovalent Complexes in the Gas Phase. J. Mass Spectrom. 2004, 39, 93-97.
30. Alexander, A. J.; Kebarle, P. Thermospray Mass Spectrometry. Use of Gas Phase Ion/Molecule Reactions to Explain Features of Thermospray Mass Spectra. Anal. Chem. 1986, $58,471-478$.

31. Tolic, L., P.; Anderson, G. A.; Smith, R. D.; Brothers, H. M.; Spindler. R.; Tomalia, D. A. Electrospray Ionization Fourier Transform Ion Cyclotron Resonance Mass Spectrometric Characterization of High Molecular Mass Starburst Dendrimers. Int. J. Mass Spectrom. Ion Processes 1997, 165/166, 405-418.

32. Samalikova, M.; Grandori, R. Protein Charge State Distributions in Electrospray-Ionization Mass Spectrometry Do Not Appear to be Limited by the Surface Tension of the Solvent. J. Am. Chem. Soc. 2003, 125, 1352-1353.

33. Juraschek, R; Dulcks. T; Karas. M. Nanospray-More Than Just a Minimized-Flow Electrospray. J. Am. Soc. Mass Spectrom. $1999,10,300-308$. 